\title{
The Rise and Decline of Australian Unionism: A History of Industrial Labour from the 1820s to 2010
}

\section{Bradley Bowden*}

In exploring the factors that contributed to the rise and decline of industrial labour in Australia, this article argues that support for unionism initially emerged from a working class that was a product of the country's unusual economic history. In the twentieth century the implementation of systems of compulsory arbitration, devised to mediate industrial conflict, reinforced support for unionism. In 1948, however, support for unionism peaked and a long process of decline began as the working class constituency that had provided its social anchor disintegrated as a result of structural changes in the economy. The dismantling of arbitration after 1986 exacerbated this established pattern of decline, as did a growth in precarious employment and employer anti-union strategies.

Pioneer union activist and labour historian, W.G. Spence, opens his famed study of the labour movement by reflecting on the unusual conditions under which European settlement in Australia began. ${ }^{1} \mathrm{He}$ went on to note that the first and most fundamental point of difference between the Australian experience and that of the Old World lay in the fact that the 'white man gave no consideration to the black man's rights'. The Aboriginal population was dispossessed of 'enormous areas', allowing for the creation of an immensely profitable economy based upon the exploitation of the land's natural resources. ${ }^{2}$ Upon this all else was built, including a union movement of unusual character whose initial mass following lay in mining and pastoralism.

In the twentieth century the peculiar nature of Australian unionism became more pronounced as arrangements for the compulsory conciliation and arbitration of industrial disputes were adopted by the Commonwealth and most states. Bolstered by this regulatory system, national union density never once fell below 40 per cent between 1913 and 1992, and was typically much higher. The central place of trade unionism in Australian life appeared immutable. However, this notion has become untenable. At the time of writing, less than 20 per cent of the workforce is unionised. What has caused this waxing and waning of support for industrial labour? While unionism clearly benefited from compulsory arbitration, and suffered from its dismantling, it is simplistic to argue, as some have done, that the growth and survival of industrial labour in this country has depended on this system of industrial regulation. ${ }^{3}$ Industrial labour existed for at least 80 years before arbitration laws were first enacted. Its rapid growth after 1900 was the result of a number of factors, not just arbitration, including the union movement's own organising efforts, an expansion of manufacturing and more favourable labour market circumstances. Nor was union decline initiated by arbitration's gradual demise. Support for unionism (measured as the percentage of the workforce who held a union ticket) peaked in 1948, when few questioned arbitration's benefits. Why then did union decline begin at this point, rather than at some earlier or later time?

In exploring, in a chronological fashion, both the history of Australian unionism and the principal debates which that history has produced in the discipline of labour 
history, this article concurs with Spence's assessment that, in the final analysis, support for unionism, and the ideals which that labour movement articulated, has rested on a working class that was a product of the nation's peculiar economic history. This is not to argue that support for unionism was ever simply an automatic response to economic relationships. Religion, gender, race, politics and community relationships at times reinforced, and at times undercut, the spread of union ideals. But it was inequitable economic relationships, both at the point of production and in society as a whole, that gave unionism its raison d'être. These economic relationships invariably affected different groups of employees in different ways. It followed that workers sought different things from unionism, with varying degrees of enthusiasm. Workers did not organise themselves into unions solely for the purpose of economic amelioration. For some, the primary purpose of unionism was that of defending, and entrenching, positions of privilege in the labour market. For others, the collective organisation of workers provided the springboard for changing society at large, not just workplace arrangements. But, despite such patterns of variance, we can identify, during the nineteenth and early twentieth century, a set of relationships which produced a working class and union movement of unique character. Industrial labour's unusual strength long reflected its following amongst those blue-collar occupations with which Spence would have been familiar - mining, agriculture and pastoralism; construction, manufacturing and transport. From the 1890s until the early 1950s this blue-collar working class consistently made up two-thirds of the workforce, providing the social anchor for the labour movement's support. The first phase of unionism's slow decline was therefore associated with the disintegration of this historic constituency. Blue-collar employment fell from 61 to 49.5 per cent of the total between the 1954 and 1971 censes. Union density declined at a virtually identical rate. ${ }^{4}$ While unionism rebounded somewhat during the 1970s the revival was over by 1981, with membership falling absolutely after 1990. By 2008 there were fewer union members than there had been in 1954. Although structural changes in the economy largely explain the initial stage of union decline such forces cannot fully account for the rapid loss of support after 1981, which was also associated with the dismantling of arbitration, a growth in precarious employment and employer anti-union strategies. Beset by far-reaching social change, industrial labour's central task has become one of winning support for the ideals of collective action among a working class that little resembles that which existed in its heyday.

Given that this study's central task is one of exploring why it was that support for unionism peaked in 1948, it uses union membership - measured in both absolute terms and as a percentage of the workforce (union density) - as the main indicator of union strength. This inevitably produces a narrowing of focus. Culture, localitybased relationships, issues of gender and ethnicity, even the role of the Labor Party, are tangential to this story and are only considered where they are seen as impacting in some meaningful way on union membership. Some of those issues are, however, given centre stage in the other articles in this special edition.

\section{Foundations: From the 1820s to 1880}

It has long been affirmed that, for all intents and purposes, 'unionism took root

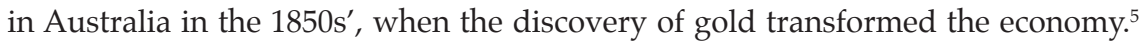
Certainly conditions for union formation prior to this date were not, as Sutcliffe 
has observed, 'conducive to Trade Union development'. ${ }^{6}$ Convicts competed with free labourers. Manufacturing was in a primitive state. The most profitable economic activities were those based upon either the extermination of the native wild life (notably whaling and sealing) or the brutal dispossession of the Aboriginal population as the pastoral sector pushed inland. In these inauspicious circumstances, worker discontent did not initially manifest itself in the establishment of unions as we understand them. Instead, as Quinlan, Gardner and Akers have shown, workers resorted to spontaneous strikes and other informal kinds of collective protest. Almost half of all pre-1851 instances of collective action were due to seafarers and whalers; a volatile workforce composed in no small part of deserters from British ships. ${ }^{7}$ The responsibility for the establishment of formal unions was left to a tiny skilled elite. The Shipwrights Society of Sydney, established in 1829, is recognised as 'the earliest of the trade societies' ${ }^{8}$ In the ensuing two decades unions were established among printers, carpenters, boot makers, tailors, bakers and stonemasons. Retail workers established Early Closing Associations in Sydney, Melbourne and Hobart. ${ }^{9}$ The policies of most early unions were exclusive as they organised to protect their relatively privileged labour market position from those who had not completed a proper apprenticeship. To achieve this objective, unions turned to employers, demanding that they only engage properly-trained tradespeople for work which they deemed to be a craft preserve. With the colonial economy suffering from acute skill shortages, such demands were often readily agreed upon. ${ }^{10}$

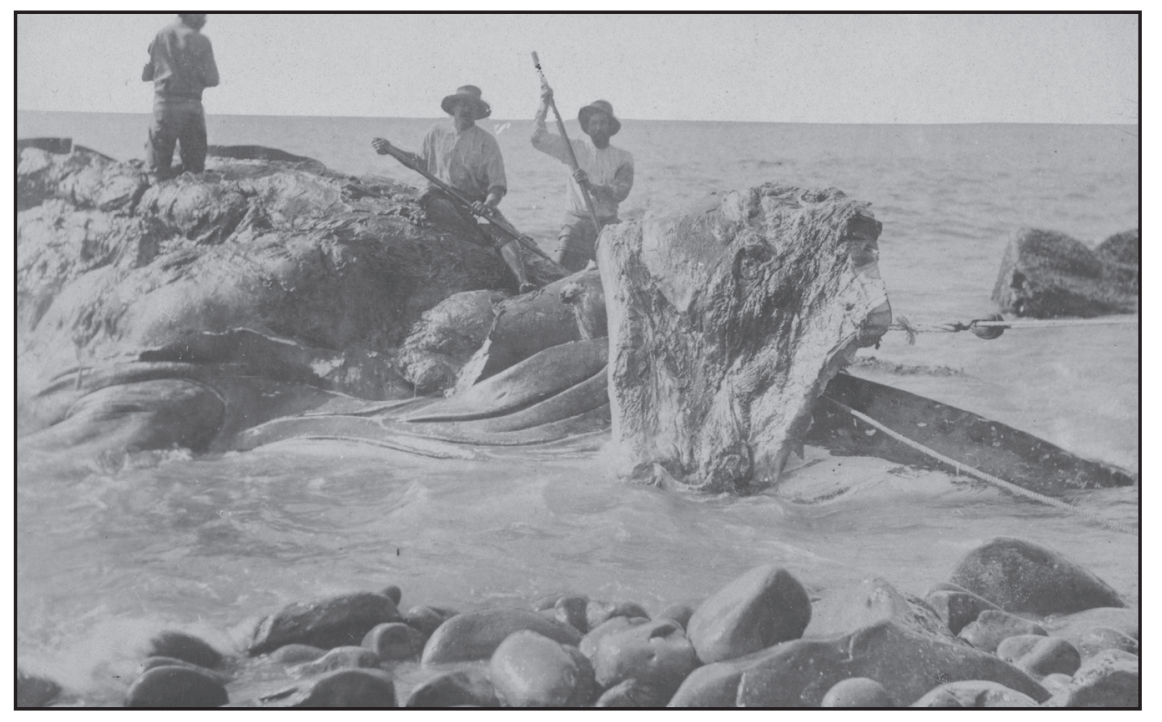

Whalers cutting blubber at Norfolk Island

In the first half of the nineteenth century whalers and sealers were the most restive section of the workforce, frequently engaging in strikes and other forms of industrial protest.

Courtesy: National Library of Australia. Bib ID: 23868153

The discovery of gold in the early 1850s had profound effects. The expansion of the mining sector meant that Australian economic development continued to diverge from the patterns found in the northern hemisphere. The largest concentrations of capital and labour were found in mining and pastoralism, not manufacturing. As late as the 1880s, Victoria's mines used more horse-power than all its factories 
combined. ${ }^{11}$ The national demographic pattern was also skewed by the gold rushes. Most immigrants were young males, producing a society where masculine values were paramount. ${ }^{12}$ Competition with Chinese miners left a racist legacy. On the other hand, many new immigrants were agreed that the inequitable Old World employment relationships should not be reproduced in the Antipodes. One leading employer later recalled how, before leaving Britain, he 'made a vow that I would do all in my power to improve working hours' in his new home. ${ }^{13}$

In the new environment created by the Gold Rushes the campaign for an eighthour day became the principal union rallying point; a struggle that has inspired much labour history research, from pioneer works by W. E. Murphy and E.W. O'Sullivan to a recent useful contribution from Kimber and Love. ${ }^{14}$ The shorter hour campaign met with early success. Sydney stonemasons won an eight hour day in 1855, their Melbourne and Brisbane workmates following suit in 1856 and 1857 respectively. The traditional explanation for this success is that the labour shortages brought about by the Gold Rushes left employers incapable of resistance. ${ }^{15}$ In fact, only a tiny minority employed by the larger building contractors initially received the shorter day. The cut in hours was, moreover, everywhere accompanied by a commensurate wage reduction, ${ }^{16}$ a concession never contemplated by British unions. This suggests that the shorter day was no unreserved union victory. Instead, it appears, employers and unions had found a practical solution to the inconstancy of work in the colonial building trade, spreading the available work over a longer time frame. ${ }^{17}$ However, the fact that the shorter day resulted from consensus, not conflict, diminished in no way the significance of the achievement. The celebration of the eight hour boon became the highlight of the labour calendar so that by the 1880s, 100,000 spectators lined the route of the Melbourne march. ${ }^{18}$

The growing historiography of Australian unionism in the 1860s and 1870s, ${ }^{19}$ which includes detailed studies of the Melbourne Trades Hall Committee (THC) and the Sydney Trades and Labor Council (TLC), ${ }^{20}$ paints a rather dismal picture of working-class and union life in this era. Hours for most workers were well in excess of the eight hour ideal. Very few workers were unionised. The Sydney TLC at the time of its founding, so Markey attests, represented only 'a small coterie of craft unions with tiny memberships' ${ }^{21}$ Attempts to broaden the union movement's base faced a number of impediments. The rapidly growing wool industry was inhospitable territory as pastoralists benefited from a 'tide of immigrants' who flooded the interior. As the sister of one sheep-king noted in 1865, the plentiful labour supply meant that her brother dismissed 'every man who does not please'. ${ }^{22}$ A shearers' union that was established in Queensland in 1875 soon disappeared without trace. ${ }^{23}$ The small-scale nature of manufacturing provided another obstacle to union growth. As W.E. Murphy noted, writing in the 1880s, the 'familiarity' between servant and master in most small workshops ensured that 'very little progress' was made in this area. Unionism in this sector was the preserve of a handful of craft unionists concentrated in the relatively few larger establishments, the most significant of which were the colonial railway workshops. The most powerful of these unions was the Amalgamated Society of Engineers (ASE), which monopolised the supply of fitters and turners. Without a coterie of ASE men, and a sprinkling of members from its specialised rivals such as the Boilermakers Society, more complex undertakings such as locomotive and ship repair were impossible. 
It was on the lower Hunter's coal fields that unionism won its first substantial following as the size of Newcastle's deposits produced large-scale operations, undercutting those ties between master and servant that hindered unionisation elsewhere. Most miners were also immigrants from British coal fields, where unionism was long established. In addition, miners shared with the owners an economic imperative that drove both to collective action - the fluctuation in the price of coal, whereby any downward movement undercut wages. This forced the union to do two things. First, it had to persuade miners that an individualist approach, where each sought to maximise their own output, was contrary to the commonweal. Second, it had to negotiate district-wide production limits with employer 'Vends'. With such imperatives at play unionism made rapid gains. The first coal miners' union was formed in May 1860. By 1879 virtually all of Newcastle's 3,659 miners held union tickets. ${ }^{24}$ During the 1880 s, Illawarra and Lithgow coal miners were also converted to unionism.

Gold miners were slower to embrace unionism than their coal mining counterparts as there was no reason for collective action to regulate fluctuating prices. The price of gold never varied, as the currency was tied to it at a fixed rate. Gold miners were also characterised by an individualistic ethos and a willingness to put financial gain ahead of safety. ${ }^{25}$ Thus, while large underground operations prevailed in Victoria from the 1860s, gold miners initially proved reluctant unionists. Even when the Amalgamated Miners Association (AMA) was established in 1874 it had trouble maintaining a following. Yet, gradually, support for unionism spread. The turning point came in 1878, when Creswick's miners successfully resisted a wage reduction by refusing to work with any but AMA men. Other mines followed their example, and by the early 1880s the union was Australia's largest, laying claim to 4,000 members. ${ }^{26}$

\section{Expansion, Retreat and Recovery: Industrial Labour 1880-1900}

By the 1880s unionism was no longer the limited preserve of skilled craft workers, miners and seafarers, as an ever expanding range of occupational groups began to exert a measure of collective control over their working lives. At decade's end close to 20 per cent of all employees were unionists. ${ }^{27}$ As membership surged so too did industrial labour's sense of intellectual vitality, exemplified in the publication of The History of Capital and Labour in All Lands and Ages, a work that must be considered the foundation stone for Australian labour history. In its opening pages, John Norton summed up the general view when he declared: 'In no other portion of the world are trades and labour organisations so numerous and effective'.$^{28}$ Structural changes in the economy help explain the union upsurge. As Butlin has emphasised, the 1880s witnessed a process of rapid urbanisation that favoured manufacturing and construction-based unions. ${ }^{29}$ Unionism became common among unskilled urban workers, particularly on and around the waterfront. It also gained a following among female workers who entered the labour market in increasing numbers. By 1890 female unionists were found in occupations such as teaching, nursing, clothing manufacture, boot making and even domestic service. While many women's unions proved ephemeral some, such as Melbourne's Tailoresses Union and Brisbane's Female Boot-Machinists Union, did win improved conditions. ${ }^{30}$ Industrial labour's most notable gains, however, were made in the pastoral industry where the Amalgamated 
Shearers Union (ASU) was established in 1886. By 1890 it claimed 20,000 members, making it Australia's largest union. Another 10,000 bush workers belonged to either the Queensland Shearers Union or the Queensland Labourers Union (the ASU did not cover Queensland). ${ }^{31}$ Union inroads in this industry reflected the utter transformation of labour relations that followed from the fencing of properties in the 1870s. A vast army of casuals tied to the shearing season displaced the quiescent workforce of shepherds that had previously typified sheep-raising. When, during the 1886 season, pastoralists cut wages the shearing workforce, many of whom had past union experiences in the AWA, sought their own union. ${ }^{32}$ Unionism also prospered on the mining fields of North Queensland, western Tasmania and at Broken Hill and thousands joined the AMA. ${ }^{33}$

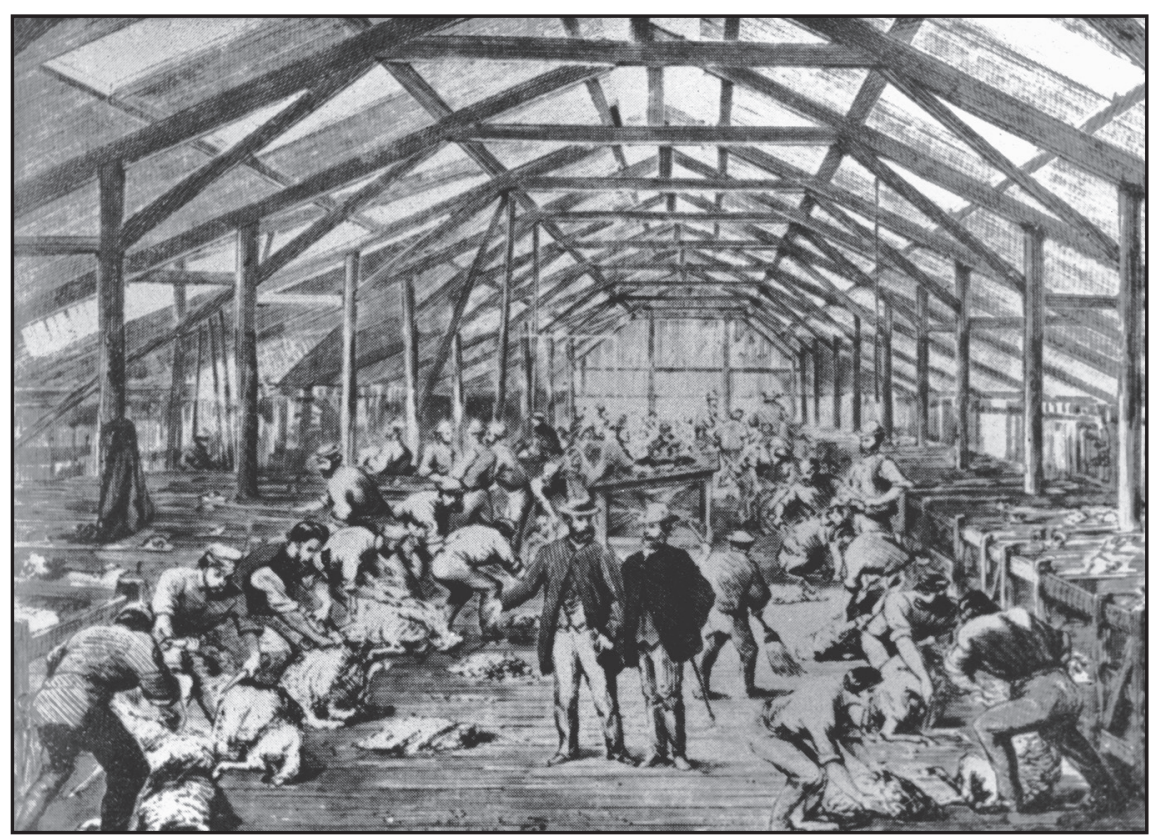

Shearers at work in a Queensland shearing shed c. 1890

In the latter half of the nineteenth century much of the union movement's mass following was found on the expanding pastoral frontier.

Courtesy: State Library of Queensland. Neg. 186974

Union success was associated with a shift away from its earlier exclusive policies. Unions pooled resources through peak councils to mobilise the unorganised: the Melbourne THC adopted an organising focus in the late 1870s and Sydney's TLC established an organising committee in 1883. ${ }^{34}$ The Trades and Labour Councils established in Hobart in 1883, Adelaide in 1884, and Brisbane in 1885 assumed a similar organising role (Perth followed suit in 1891). ${ }^{35}$ This policy shift is, in part, explained by the introduction of new technologies that undermined the position of the unionised craftsmen in a number of trades. ${ }^{36}$ In clothing manufacture and boot making, for example, the advent of cheap sewing machines resulted in most work being carried out by females and juveniles. ${ }^{37}$ Many unionists came to the conclusion that such work posed less of a threat if it was brought within the union umbrella. 
Union growth was not just a product of changing labour market relationships and better organising. Intellectually and culturally the late 1880 s and early $1890 \mathrm{~s}$ were vibrant times for the labour movement. A flourishing labour press reached a mass audience through weekly newspapers such as the Boomerang and the Worker in Brisbane, the Workman and the Worker in Sydney, the Hummer in Wagga Wagga and, from 1897, the Toscin (later Labour Call) in Melbourne. Writing in late 1890, the Secretary of the Barcaldine-based General Labourers Union noted: 'The workers in the country are as eager to have a look at the Worker paper as they are to partake of their evening meal ... the bushmen as a rule are great readers' ${ }^{38}$ In the cities, so Bruce Scates records: 'Socialists, anarchists and single taxers set up stalls at almost every radical venue, peddling newspapers, books and pamphlets from parks, wharves and street corners' ${ }^{39}$ Fluid and politically heterogeneous, Australian radicalism in this era owed far more to the utopian socialism of Edward Bellamy and the ideals of Henry George, who believed graduated land taxes would eventually bring about public ownership of landed property, than they did to Karl Marx. ${ }^{40}$ In the populist ideology that became the hallmark of labour thinking, the fundamental social divide was between 'working people' of all sorts (including farmers and small-business operators) and greedy monopoly interests. ${ }^{41}$ Admittedly, the extent of support for this political radicalism remains a matter of conjecture. While scholars such as Gollan, Scates, Burgmann and Love, as well as pioneer activist-historians such as Spence and Ernie Lane, ${ }^{42}$ have argued that labour radicalism won a mass following in this era, others, notably Nairn, Dalton and Murphy, contend that the thinking of most workers and activists continued to reflect the prevailing ethos of colonial liberalism, with its belief in piece-meal reform. ${ }^{43}$ But, if labour radicals were a minority even within the ranks of organised labour (itself a minority movement) their contribution should, nevertheless, not be underestimated. By helping to define a growing, if still loosely defined, sense of class identity their activities and ideals gave organised labour 'a world vision ... that was fundamentally opposed to the world-vision of the rich and powerful' ${ }^{44}$

Despite the labour movement's organisational and intellectual vigour, it is now evident that overall trends in the colonial economy were not as favourable for unions as was once believed. Over the last two decades there has been a growing questioning of the view, put forward principally by Noel Butlin and R. V. Jackson, that Australia in the 1880s was 'a seller's market for labour' ${ }^{45}$ As Shirley Fitzgerald, Max Cannon and other researchers have amply demonstrated, such conclusions are at odds with the marked social disparities and abysmal living standards that often characterised working-class life. ${ }^{46}$ Other scholars have highlighted the marked seasonal and cyclical variations in the labour market, which reduced both the annual wage and industrial bargaining power of many workers. ${ }^{47}$ Union power in manufacturing was diluted by the employers' use of so-called 'improvers', who picked up skills informally on the job rather than through a union-approved apprenticeship..$^{48}$ Placebased relationships, while reinforcing support for unionism in some localities, such as the Hunter's coal mining districts, curtailed union strength in other areas. In Queensland's principal coal mining district, based around Ipswich, for example, unionism maintained, at best, a fitful existence. Mines on this field were much smaller than those in the Hunter, thus fostering familiarity between master and man. Ipswich's workers also looked to the district's employers for leadership in religion, 
culture and politics. ${ }^{49}$ In the metropolitan centres the transient nature of much of the population undercut bonds of common acquaintance among workers, hindering collective activity. ${ }^{50}$ Endemic racist attitudes within the labour movement ensured that few workers of non-European ancestry had the benefit of union membership. Advocacy of a 'White Australia' was a constant refrain. ${ }^{51}$ Racial exclusion meant that large workforces, central to the functioning of the economy, remained industrially unregulated. This was particularly the case in northern Australia. Aboriginal children, many of them seized by force from their homes, were widely employed as domestic servants throughout the interior. ${ }^{52}$ In Queensland, the importation of 59,000 indentured Melanesian labourers between 1863 and 1904 sustained that colony's all-important sugar industry. ${ }^{53}$ One union at least, the ASU, did allow for Aboriginal members, recognising their prior occupation of the land. In the 1890s an Aboriginal shearer, William Ferguson, even served as a union organiser. ${ }^{54}$

Although there were limits to union power, employers were nevertheless alarmed by industrial labour's growth. Perhaps inevitably, this growth provoked an employer counter-offensive. Defeated in the Great Strikes of the early 1890s, unions were further weakened by the economy's slide into depression with unemployment reaching 30 per cent. The mass of small, city unions disappeared. We need, however, to be wary of seeing the 1890 s as a decade of total defeat. The labour press continued to expound the benefits of union organisation. Socialists and other labour radicals still agitated for a new social order. Unionism fared best in the mining and pastoral districts. In 1901, primary pursuits still provided almost one-third of all jobs while only 16.8 per cent of the workforce was found in manufacturing. ${ }^{55}$ These circumstances favoured the growth of general workers' unions who recruited members from across a variety of outback occupations. The most famous of these was, of course, the Australian Workers Union (AWU), formed in 1894 from the merger of the ASU and the General Labourers Union. In Queensland, the membership of another pastorally-based general workers' union, the Amalgamated Workers Union, almost certainly exceeded that of all other unions combined. ${ }^{56}$ Unionism also retained a strong following amongst miners. At Broken Hill, despite constant management attack, one-third of the workforce remained loyal. ${ }^{57}$ On the Western Australian gold fields the Amalgamated Workers Association united miners, making it the colony's largest union. ${ }^{58}$

Spence famously argues that the Maritime Strike of 1890 was the 'great turning point in the history of Australian Labor' ${ }^{\prime 59}$ Defeated in the strike, he wrote, unions sought political power, formed Labor parties and became advocates of arbitration. While the controversy over the strike's role in giving birth to the Labor Party is best left to the separate article in this edition, it is certainly true that industrial labour's subsequent close ties with Labor immeasurably strengthened its social and political influence, as both wings of the labour movement contested power in the nation's workshops, pubs and homes. Indeed, in his famed account of the Australian labour movement, V.G. Childe declared: 'The labour movement in Australia takes on its special character only from the date of its entry into the political arena ... Up to this point the history of unionism in the Australian colonies presents no features to make it worthy of special attention. ${ }^{\prime 60}$ An amalgam of forces - including socialists, single tax supporters and farmers - the colonial Labor parties were nevertheless clearly dominated by the unions who affiliated to them, drawing the bulk of their 
support from manual workers in both the cities and the bush. While, as Rickard notes, the growth of Labor parties both reflected and reinforced the growing sense of 'working class consciousness', ${ }^{61}$ tension was soon evident between the political wing, desirous of widening its social appeal through a more moderate platform, and the industrial wing, intent on retaining Labor's distinctiveness. As Gilbert Casey, a leading Queensland unionist, declared in 1892: 'The question for the future is whether the people are going to boss the political machine or whether the political machine is going to boss the people'. ${ }^{62}$ One issue that was central to organised labour's internal debates was compulsory arbitration. While historians long accepted as gospel the view that defeat in the Great Strikes made unions proponents of arbitration, ${ }^{63}$ it is now evident that the most enthusiastic supporters of the concept were Labor's politicians, eager to win the support of middle-class voters who had become alarmed by trade union strike action. In New South Wales, for example, the TLC did not endorse arbitration until 1898. Even this endorsement, Markey argues, merely reflected the views of 'a small group of conservative craft unions which were unrepresentative of craft unionism, let alone unionism as a whole' ${ }^{64}$

\section{Arbitration and the Rise of Labourism, 1900-21}

In the two decades after 1900 industrial labour made the most momentous advances in its history. By 1920 unions, for the first time, represented more than 50 per cent of all employees. This remarkable advance corresponded to a growth in the state regulation of industrial relations. Most scholarly attention has focused on the introduction of state and federal systems for compulsory arbitration. Devised as a mechanism for mediating industrial conflict, arbitration provided unions with a number of benefits. Once registered, a union's existence was guaranteed as no rival could enrol its members. Employers were forced to bargain with it. Arbitration court awards set legally binding working conditions and also, over time, typically gave preference in employment to unionists. ${ }^{65}$

The temporal association of union growth with the introduction of arbitration has caused historians to ponder the link between the two. William Howard, in particular, has argued that it was a close one, and that Australian unionism, 'all-but-obliterated' in the 1890s, was essentially born anew after 1901, 'being called into existence by a bureaucratic mechanism (the arbitration system)' ${ }^{66}$ This view is an extreme one that is not supported by the facts. The Commonwealth arbitration system only became operational in 1905, and in its first decade covered relatively few workers. At the state level, only Western Australia and New South Wales had arbitration systems in place from 1900, and even these disappointed union activists. In the other states, wages boards - which did not give unions any formal status - regulated working conditions for most of the period (Queensland opted for arbitration in 1916). Downplaying the role of arbitration, both Cooper and Markey argue that the organising campaigns undertaken by revitalised peak councils were decisive in union growth. In corroborating this conclusion, Cooper notes that one-third of the unions registered in New South Wales in 1910 owed their existence to the Sydney TLC's Organising Committee. ${ }^{67}$ Sheldon has also highlighted how unions benefited from a marked upswing in employment opportunities. ${ }^{68}$ Certainly, market circumstances favoured union revival as the economy grew by 41 per cent between 1905/06 and $1913 / 14{ }^{69}$ The introduction of a national system of tariff protection also fostered 
union growth. Under the Lyne tariff of 1908 the duties on most imported goods were doubled, providing a massive boost to local industry. Guaranteed higher prices for Australian-made products were, in the eyes of the Deakinite liberal architects of tariff protection, a prerequisite for the payment of 'fair' wages to workers. ${ }^{70}$ This mutually beneficial arrangement, it was hoped, would underpin both arbitration and a new cooperative era of union-employer relations.

If it is wrong to argue, as Howard has, that union growth after 1900 was almost solely attributable to arbitration, we should nevertheless be circumspect about adopting a totally contrary view. Even the distant hope of a wages board determination or arbitration court award was enough to inspire many disorganised workers to form a union. It was, for example, the prospect of a wages board determination that led to the establishment of the Victorian Carters and Drivers Union in September 1900. When these expectations were dashed, the union turned to the Commonwealth Conciliation and Arbitration Court, registering itself as the Federated Carters and Drivers Industrial Union - the forerunner of the Transport Workers Union (TWU) in 1906. ${ }^{71}$ While organising campaigns were often responsible for union formation it was usually arbitration that sustained them. The Watchmen, Caretakers and Cleaners Union (WCCU) - the forerunner of the Liquor, Hospitality and Miscellaneous Workers Union - is a case in point. Formed as a result of the Sydney TLC's organising activities in 1910, the WCCU was, so the union's historian concludes, only 'viable' because of arbitration. ${ }^{72}$ Arbitration also provided a boost for white-collar unions, particularly in the public service where government by-laws had previously restricted membership. Unions covering tramway and rail workers also gained from arbitration, as unionism spread from skilled workshop employees and engine-drivers to embrace porters, cleaners and other semi-skilled positions. ${ }^{73}$

One adverse effect of arbitration was to entrench existing labour market divisions based on skill and gender. In his famed Harvester Judgement of 1907, Justice Higgins refused payments for 'improvers', thereby denying employers a well-tested device for circumventing the need for skilled craft workers. ${ }^{74}$ In addition, craft workers gained a 'margin' for skill, set 30 per cent above the 'living wage' provided for unskilled male labourers. Higgins' 'living wage' judgement also endorsed the view that paid employment was properly the duty of an adult male, who was granted a wage sufficient to support a wife and three children. In 1912, Higgins explicitly rejected the concept of female equal pay, subsequently setting the federal basic wage for women at 54 per cent of the male rate. ${ }^{75}$ Male unionists also used the new wages' systems to restrict female employment opportunities. In the clothing trades, the Secretary of the Federated Clothing Trades Union recounted that his union's representatives 'deliberately refrained from using their best endeavours to improve the lot of women'.$^{76}$ Given such attitudes it is not surprising that in 1912 only 17,670 of the nation's 394,719 female breadwinners had a union ticket. ${ }^{77}$

Arbitration also underpinned the rise of a 'labourist' ideology that soon dominated the thinking of most unionists. While the concept of labourism is much debated in labour history, Hagan's definition has the widest acceptance. According to Hagan, exponents of labourism argued that the interests of (white male) workers were best advanced through a White Australia policy, arbitration courts, a system of tariff protection and the election of Labor governments. ${ }^{78}$ In a mutually beneficial arrangement, the dramatic increase in union membership that was underpinned by 
arbitration helped boost Labor's vote, which rose federally from 18.7 per cent in 1902 to 50 per cent in $1910 .{ }^{79}$ In Rickard's well-argued view, the enforcement of arbitrated awards reinforced a growing sense among 'working-class people' that they were members of a distinct 'working-class' whilst, simultaneously, providing them with the means for amelioration of their plight without recourse to class conflict. ${ }^{80}$ The White Australia Policy and arbitration also reinforced the ethnic domination of the Anglo-Celtic majority. In 1901, only 3.7 per cent of the population were born in nonAnglophone countries. Despite limited migration from non-British countries, notably Italy and Greece, in the decades after 1901, the percentage of the population born outside the Anglo-Celtic world fell to 1.9 per cent by 1947. Where workers drawn from ethnic minorities were employed the award system ensured that employers could not use this labour force, as they often did in the United States, to undercut established working conditions. ${ }^{81}$

One of the most fruitful pursuits in Australian labour history in recent decades has been the exploration of how support for organised labour in the opening decades of the twentieth century were mediated by forces embedded within individual communities and localities. From such works - which include studies that encompass the Sydney suburbs surrounding the Eveleigh railway workshops, the Western Australian railway centre of Midland, the Melbourne working-class suburb of Richmond, the Victorian mining town of Bendigo, Lithgow and Broken Hill in New South Wales, and Ipswich and Rockhampton in Queensland ${ }^{82}$ - a number of conclusions stand out. First, by 1914 industrial labour's sheer numerical strength ensured a marked impact on all the institutions of civic society, whether they be religious, political or industrial. Taksa, for example, notes how the concentration of thousands of unionised railway workers at the Eveleigh workshops impacted on the social and political life of at least eight surrounding Sydney suburbs. ${ }^{83}$ Second, the return of union-supported Labor candidates created 'networks of civic engagement' based upon reciprocity. In return for votes, Labor politicians assisted their communities in a variety of ways. Sometimes, as was the case in Richmond, this quickly degenerated into nepotism, financial kickbacks and other forms of petty corruption. ${ }^{84}$ More commonly, it involved political interventions that favoured local unions and their members in a myriad of ways, ranging from direct support of industrial objectives to state support of local industries.

If support for labourism became deeply embedded in many working-class communities, within the union movement there was no more passionate exponent of the concept than the AWU. The union skilfully exploited the opportunities offered by arbitration. The handing down of a federal pastoralist award in 1907 guaranteed its position in outback Australia. By 1914, following a merger with Queensland's largest union, the Amalgamated Workers Association, one Australian unionist in eight held an AWU ticket. During World War I its strength was further augmented by a merger with the successor to the AMA. This gave the AWU coverage of hard-rock miners (Broken Hill's miners remained aloof, retaining their militant traditions). Such developments meant that in rural and regional Australia, as the union's historians note, the union possessed a virtual 'organising monopoly'.$^{85}$ In rural areas the union also effectively controlled the Labor Party. ${ }^{86}$

Support for labourism did not go unchallenged. Many unionists became disappointed with arbitration's fruits. As Peter Macarthy's groundbreaking research 


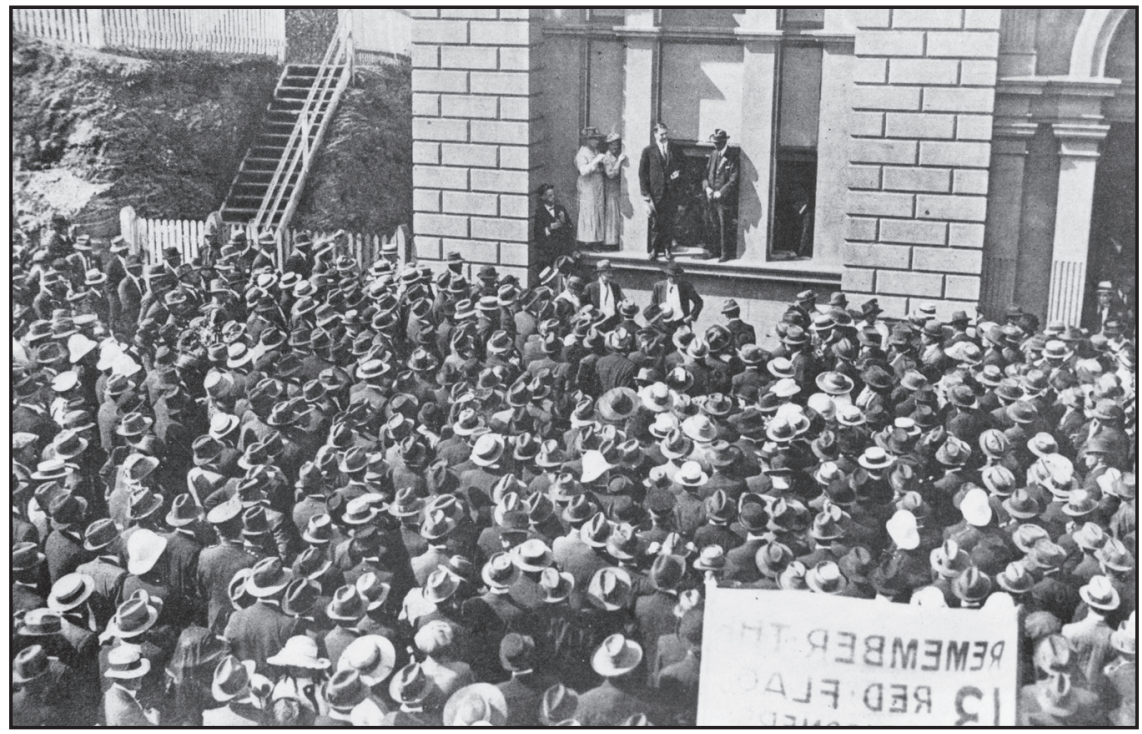

A crowd of workers gathers outside the Brisbane Trades Hall, 1919

In the aftermath of World War I workers were increasingly attracted to radical political and industrial causes.

Courtesy: State Library of Queensland. Neg. 18143

revealed, Higgin's 'living wage' was initially 'little more than a pious expression of a social ideal', applying only in the minority of workplaces covered by federal awards. ${ }^{87}$ Moreover, its value was soon eroded by inflation. Many disaffected workers were attracted to the revolutionary ideas of the Industrial Workers of the World (IWW). Originating in Chicago in 1905, the IWW soon won a significant Australian following. ${ }^{88}$ Worker discontent mounted during World War I. In 1917, more days were lost to strike action per worker than in any other year in Australian history, before or since. In this climate, support for the One Big Union (OBU) movement also grew. OBU advocates, while not necessarily endorsing the IWW's revolutionary ideals, shared with them the belief that all workers should be in one huge union. In 1919 an Australian-wide conference endorsed this ideal. However opposition from the Labor Party, the AWU and craft unionists strangled the new body in its infancy. ${ }^{89}$

Sociologically, Australia remained through these times a society where an overwhelming majority earned their living with their hands. In 1921, as in 1901 (and 1891), two-thirds of breadwinners were engaged in manufacturing, construction, transportation, mining or rural work. There was, however, a shift in emphasis. By 1921, almost 20 per cent of the workforce had factory jobs. The growing importance of manufacturing happened at a propitious time for unions. Employment in hard-rock mining declined markedly after 1911 as historic fields such as Charters Towers were worked out. A collapse in demand for metal ores at the end of World War I also added to the industry's woes. ${ }^{90}$ Hence, whereas in 1911 miners made up 7.4 per cent of the workforce, by 1921 they comprised only 2.9 per cent..$^{91}$ In the rural sector, as well, there were few avenues for union expansion after 1901 (the Queensland sugar industry being the major exception). Opportunities for unions were better in manufacturing where binding awards made the task of organising small workshops easier. Union 
representation was extended to many when the most important manufacturing union, the Amalgamated Engineering Union (AEU) - formerly the ASE - opened its doors to the semi-skilled in $1920 .{ }^{92}$ By 1921, manufacturing accounted for 230,035 of the nation's 703,009 unionists. By contrast, there were only 87,840 unionists in pastoralism, agriculture and mining combined. Manufacturing had now become industrial labour's principal stronghold. ${ }^{93}$

\section{Apogee: 1921-54}

Between 1921 and the mid-1950s unionism commanded a central place in Australian society. Even in the depths of the Great Depression, union density never fell below 42.5 per cent. As the economy recovered during World War II unionism won unprecedented support. In 1948 union density reached an all-time peak when 64.9 per cent of the workforce had a union ticket. It remained above 60 per cent throughout the early 1950s. While, no doubt, many unionists joined only because of union preference clauses it was also the case that countless others were deeply committed to the union cause. Unionism was socially anchored in the rituals of working people's lives. Unions ran social and cultural activities, as well as educational classes. Acceptance of collectivist union values reflected, in no small part, the fact that there was little change in the nation's class structure in the first half of the twentieth century. In every census between 1891 and 1947 the percentage of the workforce engaged in blue-collar occupations hardly varied, remaining constant at around two-thirds of the total. Few workers of blue-collar origin could aspire to a successful business or even professional career. ${ }^{94}$ A career as a union official, or Labor parliamentarian, was one of the few means of escape from the shop floor. ${ }^{95}$ Generational experience indicated that an improvement in one's lot could only be won through collective, not individual, action.

The stability of this unionised, working-class society, and the collectivist values embedded within it, were underpinned by two government-mandated policies. The first was tariff protection which insulated manufacturing from the Depression's worst effects. ${ }^{96}$ By 1939 factory work provided jobs for 351,292 union members 38.4 per cent of the total. Much of this growth was in large-scale operations such as the Newcastle and Port Kembla steelworks. Arbitration played an even more significant role in maintaining union strength as the award system gave unions the ability to regulate working conditions even during adverse economic circumstances. Union preference clauses also ensured there were no mass defections from union ranks. In general, unions did much better under Labor governments than under their conservative opponents. With Labor holding the treasury benches in the Commonwealth Parliament only once (1928-31) between 1915 and 1941, unions no longer found the federal arbitration system as sympathetic to their interests as it had previously been. Where possible, New South Wales, Queensland and Western Australian unions switched to state jurisdictions where Labor governments prevailed during the 1920s; a trend that weakened many of the federal unions established prior to World War I in pursuit of a commonwealth award. Even state awards, however, could not protect unionists from a change of government. The adverse consequences of a conservative victory were, perhaps, best demonstrated by the Queensland experience where Labor lost power in 1929, only to regain it three years later. On the eve of the 1929 poll, union density stood at 68 per cent. By 1932, however, it had 
fallen to 45.4 per cent as the incoming government abolished union preference and withdrew award protection from public servants and agricultural workers. When these measures were repealed by a new Labor government in 1932, union density immediately rebounded and by 1935 was again close to 60 per cent. ${ }^{97}$

From the fact that arbitration underpinned, and legitimised, industrial labour's place it does not necessarily follow, as some scholars have argued, that it was a substitute for union activism. ${ }^{98}$ As Cooper and Patmore note: 'Preference clauses and right of entry for union organisers were not necessarily granted by the arbitration system nor respected by management'. ${ }^{99}$ Rather than becoming an alternative to organising, the award became the focal-point around which organising occurred. This is vividly demonstrated in Barbara Webster's studies of arbitration's impact on union behaviour in Rockhampton between 1915 and 1957. Rockhampton's union leaders were invariably pro-arbitration but they were not tame bureaucrats. Frank Conlon, the local TWU head, typically began his working day at 4.30am, policing workplaces and inspecting time-sheets to ensure compliance with the award. In the city's railway workshops and at its meatworks (the largest in the Southern Hemisphere) union leaders actively supported shop committees that were entrusted with day-to-day enforcement of the union's awards. ${ }^{100}$ Webster's portrayal of an active rank-and-file, mobilised around the defence of award benefits, is supported by a series of studies of industrial life at Western Australia's Midland railway workshops. ${ }^{101}$ Here, as at Rockhampton, arbitrated awards were at the centre of shop floor activism. 'Each shop steward' at Midland, Lenore Layman writes, 'was responsible for ensuring that the union's award was not breached' ${ }^{102}$ However, arbitration imposed strict limits on workplace activism. Shopfloor delegates were rarely empowered to negotiate hours of work or wages, tasks left to union leaders and arbitration court judges.

Industrially and organisationally the years between 1921 and 1950 were ones of historic achievement for industrial labour. In May 1927 the Australian Council of Trade Unions (ACTU) was formed. Long-term OBU advocates would have been disappointed by the new body, which was simply imposed atop existing structures. The ideal of uniting all within one great union was permanently abandoned. The ACTU, nevertheless, provided unions with a hitherto lacking national voice. ${ }^{103}$ Industrially, a 44.hour week became commonplace during the 1920s as state Labor governments legislated for shorter hours. Unions then agitated for a 40 hour week; a boon conceded by the Commonwealth Arbitration Court in 1947. Women workers also made gains. As males joined up during World War II the number of females at work rose from 644,000 in 1939 to 855,000 in 1944. Wartime regulations deemed that those working in vital industries should receive 75 per cent of the male rate. However, this rate did not become universal until 1950 when it was finally endorsed by the Commonwealth Arbitration Court. By then, returning servicemen had forced many women out of the workforce. ${ }^{104}$

The union movement's mass-following meant that any political struggles within its ranks resonated widely. During the interwar years 'labourist' domination of the union movement was challenged by the Communist Party of Australia (CPA). Formed in 1920, the CPA had only a few thousand members in the interwar years. Nevertheless, by the 1930s they had won control of some of the nation's more militant unions, including the Miners Federation, the Waterside Workers Federation and the Seamen's Union. The party gained ground during World War II, claiming 


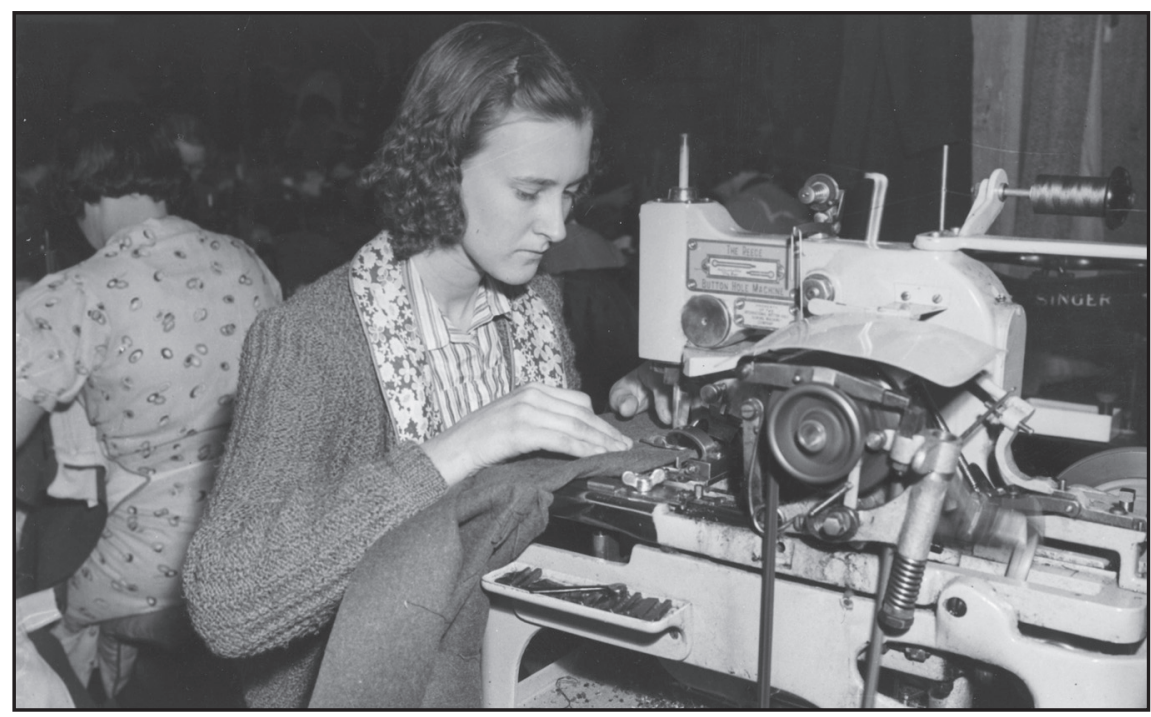

Female clothing worker producing army uniforms, 1940

Female participation in the workforce reached a new peak in World War II.

Courtesy: State Library of Queensland. Neg. 161601

23,000 adherents in 1945. It is estimated that at this point communists represented 40 per cent of all unionists. ${ }^{105}$ Workplaces were turned into lecture rooms where workers were extolled on the benefits of socialism. In a common lament, one manager complained that in 1945 one of his union delegates spent most of his day 'talking about communism'. Whenever his speeches began, the manager testified, all the workers 'would stand and listen' ${ }^{106}$ Under threat, the Labor Party endorsed the formation of Industrial Groups to combat communist influence. The Groups won some notable successes, wresting unions such as the Federated Ironworkers Association and the Clerks from communist hands. Unfortunately for Labor the Groups were an unstable coalition of old-style 'labourists', led by the AWU, and supporters of the Catholic Social Studies Movement. The latter was established in 1944 by B. A. Santamaria with the full support of the nation's Catholic bishops. The Movement, whose members comprised up to 90 per cent of the Group's rankand-file, ${ }^{107}$ was no natural Labor ally. Its leaders wanted to reform the Labor Party along Christian-Democratic lines by encouraging small ownership and a return to the land. The result was a three-way tussle for control of labour's political and industrial wings. ${ }^{108}$

In the late 1940s Australia witnessed a wave of strikes as unions in the metal trades, the meat industry and the railways refused to be bound by arbitration. Communists were prominent in these disputes, leading to allegations that they were using industrial disputation to foster revolution. Divisions within the labour movement came to a head in 1949 when coal miners struck work; a dispute that ended in defeat when the Labor Prime Minister, Ben Chifley, sent the army in to work idle pits. Of all the tumultuous events of this period none has caused greater scholarly disagreement than this 1949 strike. A number of prominent historians, including Jim Hagan and L. F. Crisp, have endorsed the popular view that the strike was largely communist-inspired. ${ }^{109}$ Others, most notably Tom Sheridan and 
Philip Deery, have emphasised the genuine industrial grievances of the miners. ${ }^{110} \mathrm{In}$ Gollan's estimation, a fear of mechanisation and the inevitable job losses did much to precipitate the strike. The subsequent defeat proved, Gollan argues, 'a turning point' for unionism in the coal industry as mechanisation 'became a fact'. ${ }^{111}$ The defeat also heralded a general loss of communist influence within the union movement. This trend, however, brought tensions between Movement supporters and labourists to the surface, resulting in the bitter 'Split' of 1956-57 when the former were effectively driven from Labor's ranks.

Despite the labour movement's deep divisions there was, in the early 1950s, nothing to suggest that industrial labour's support was about to experience a precipitous decline. On the contrary, full employment, and a continued growth in manufacturing, created a most favourable environment. In 1954 the manufacturing workforce accounted for 28 per cent of all jobs (a peak that was never surpassed) and 34 per cent of the union movement's membership. ${ }^{112}$ Industrial labour also claimed a record 335,743 white-collar members. Despite these latter additions, however, unionism (and paid employment) remained an overwhelmingly blue-collar phenomenon. In 1954, 70.1 per cent of the union movement's total strength was found in blue-collar jobs. From the mid-1950s, however, blue-collar work lost much of its former importance, undermining the strength of many long-established unions.

\section{The Long Decline, 1954-2010}

In a recent history of Australian unionism, Tom Bramble declared that the period between 1968 and 1974 represented 'the flood tide' of Australian unions. In these years, Bramble argues, a spike in union militancy brought record numbers into union ranks. ${ }^{113}$ In truth, the high-water mark for union strength - when measured as the proportion of the workforce who held a union ticket - was 1948, when 64.9 per cent belonged, not 1974. In the 16 years after 1954 union density dropped from 62 per cent to 49 per cent. ${ }^{114}$ Structural changes in the economy were largely responsible for the change in union fortunes. Between 1954 and 1971 the percentage of the workforce engaged in highly unionised blue-collar occupations fell from 61.1 to 49.5 per cent. Absolute membership fell in shipping and stevedoring, mining, agriculture and pastoralism, rail and tram transport and in building. Mechanisation explains much of this decline. The switch from steam to diesel power in the railways eliminated coal jobs as well as those of rail workers. In agriculture, and on the waterfront, bulk-loading reduced employment. In Cairns, for example, the number of waterside workers fell from 518 in 1955 to 99 in 1962. Only the strength of the manufacturing sector saved the union movement from an even more precipitous decline. Between 1954 and 1970 the number of unionised factory workers grew by 25.8 per cent. ${ }^{115}$

The sustained fall in union support was reversed in 1970 and in the ensuing five years union density rebounded by seven percentage points to 56 per cent. Gains among white-collar workers explain this turnaround. While, as this article has noted, unionism had had a significant white-collar following by 1920, this workforce grew steadily from the early 1950s. Much of this growth was in part-time, largely female, jobs in retailing and hospitality - traditionally poorly unionised sectors where the organisation of workers was impeded by the predominance of small firms. At the other end of the spectrum were professional and semi-professional occupations such as nursing and teaching where unionism was historically strong. In between were a 

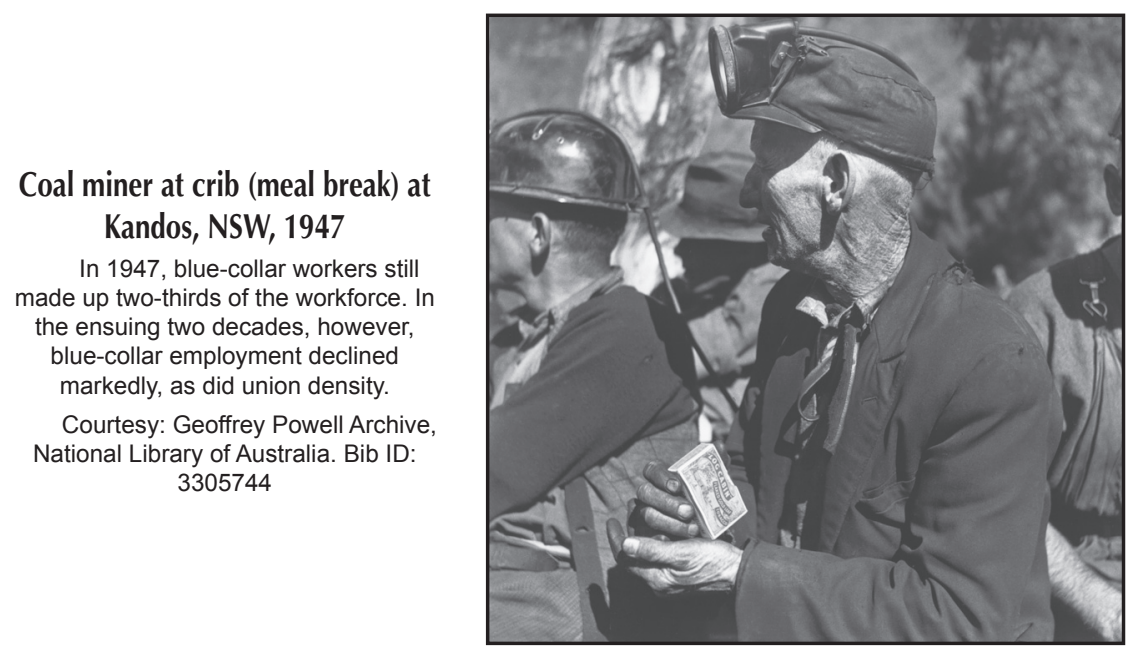

mass of clerical and administrative workers employed in both the private and public sector. It was the unionisation of this latter group that was largely responsible for the sudden surge in union density as the number of white-collar unionists rose by 89 per cent to 1.2 million between 1969 and $1981 .{ }^{116}$ Arbitration, and the enforcement of union preference clauses, played a key role in this advance. Griffin estimates that the Commonwealth Conciliation and Arbitration Commission's decision to grant members of the Federated Clerks Union employment preference for clerical work in the oil industry boosted that union's membership by 20,000 between 1971 and 1976. ${ }^{117}$ Major employers in retailing and banking and insurance also agreed to enforce compulsory unionism. ${ }^{118}$ The most spectacular advances occurred in the public sector, where unionism was well established. The Australian Public Service Association's membership more than doubled between 1970 and $1974 .{ }^{119}$ Pro-union government policies were pivotal in such gains. In 1970 the McMahon Liberal government introduced automatic deductions for union fees. The Whitlam Labor government was overtly pro-union, threatening to withhold an extra week's annual leave from non-unionists in 1973. Greater white-collar militancy, and marked gains in working conditions, also bolstered recruitment. ${ }^{120}$

Thus a fundamental change in the union movement's complexion occurred. By 1981, white-collar workers made up almost 40 per cent of all unionists, compared to 28 per cent in $1969 .{ }^{121}$ The workforce, and the union movement, also became increasingly feminised. By 1981, 36.5 per cent of breadwinners were women. Most of new union members won in the white-collar sector were women. At the Federated Clerks there were almost four female recruits for every male one. ${ }^{122}$ Unions covering nursing and teaching, both female-dominated occupations, also grew strongly. Ethnically, the Australian labour force experienced far-reaching change as, after 1947, Australian governments embarked on a program of mass immigration that increasingly drew on populations from Eastern Europe, the Middle East and Asia. By 1988, over four million migrants had landed on Australian shores. Relative to the host population, only Israel and Switzerland experienced a larger, and more ethnically diverse, migrant influx. With the Whitlam government's formal abandonment of the White Australia policy there was a sharp increase in Asian 
migration and by the mid-1980s more than half a million Australian residents were Asian born. ${ }^{123}$ By the 2006 census, 48.7 per cent of the Australian population had at least one parent born overseas. ${ }^{124}$ Despite its long support of the White Australia policy, the union movement willingly endorsed post-war migration. High levels of employment growth, and the continued protection of the award system, ensured a ready integration of immigrant workers. ${ }^{125}$

Despite the profound economic and social changes that were reshaping the contours of the Australian workforce the union movement initially retained its militancy with large-scale wage increases being won through strike action between 1970 and 1981. Workers in road transport and the metal trades, unaffected by the decline in blue-collar employment elsewhere, led the way. The most spectacular wage victory in Australian history occurred when the TWU won a $\$ 25.40$ increase in 1974; a gain which increased the wage of road transport workers by almost onethird. ${ }^{126}$ Unions also used their industrial strength to redress long-standing inequities based upon gender and race. Following ACTU applications to the Commonwealth Conciliation and Arbitration Commission in 1969 and 1972 the vast majority of the nation's 1.8 million female workers gained 'equal pay for equal work'. The female-to-male earnings ratio jumped from 0.6 to 0.8 , rising faster than anywhere else in the world in the 1970s. ${ }^{127}$ When, in 1966, the Northern Territory's Gurindji people set up a strike camp and demanded the return of their ancestral land, the Waterside Workers Federation and building unions provided support. Unions also became environmentally conscious. Here the New South Wales Branch of the Builders Labourers Federation (BLF) under the leadership of Jack Mundey led the way, imposing 'Green bans' to protect bush areas and working-class residences in Sydney's Rocks district and at Woolloomooloo. ${ }^{128}$

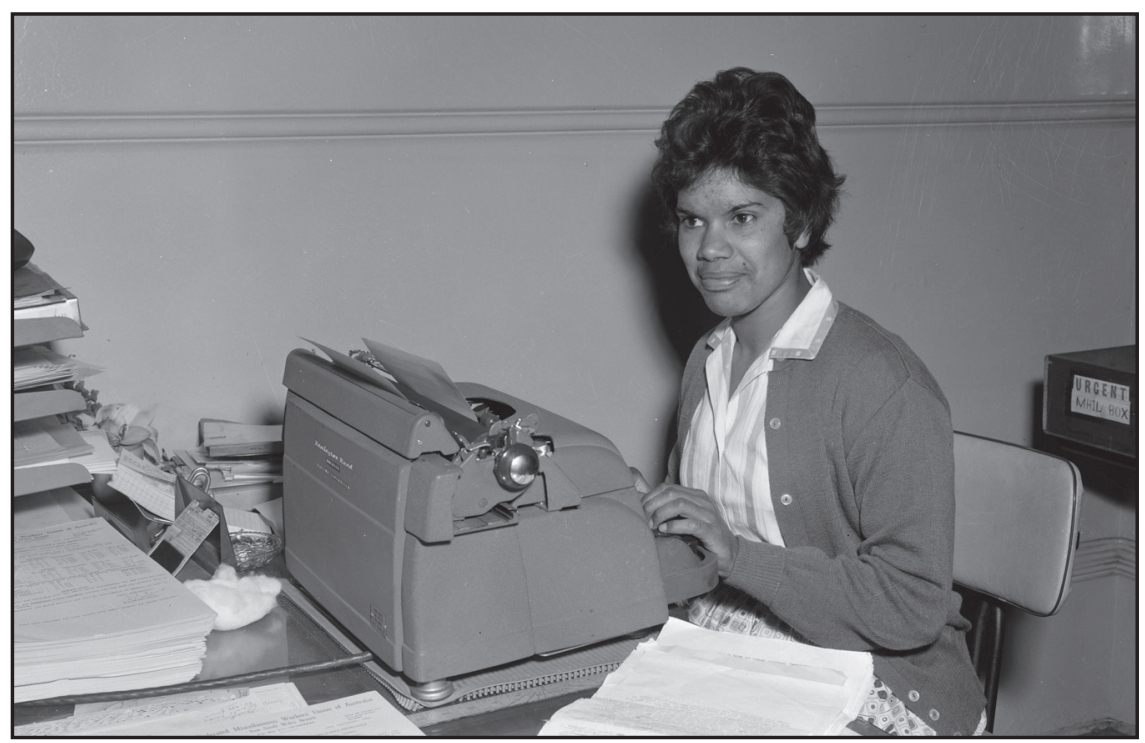

Aboriginal employee of the Miscellaneous Workers Union, Sydney, 1962

By the early 1960s the union movement was at the forefront of campaigns to enhance Aboriginal rights and working conditions.

Courtesy: Mitchell Library, State Library of NSW. Call No. Australian Photographic Agency 22303 
Militancy disguised growing threats to union growth. Imports, rather than homemade goods, increasingly filled the retail shelves. Another mining boom, based upon open-cut mines in Western Australian and Queensland, caused the value of the dollar to soar, thereby making imports cheaper. A 25 per cent tariff cut, enacted by the Whitlam government in 1973, made imports even more attractive. Large-scale salary increases added to manufacturers' woes. ${ }^{129}$ In 1974-75, and again in 1981-83, the economy slipped into recession. Unionism in the private sector was hit hard and by early 1982 only 39 per cent of privately-employed workers were unionised. The TWU, which had played a leadership role in the wage campaigns of 1974 and 1981, lost 10 per cent of its membership in the recession of 1981-83. Manufacturing-based unions were also decimated as 200,000 factory jobs disappeared between 1974 and 1984. ${ }^{130}$ Beset by such losses, overall union density fell sharply, to 49.5 per cent. The public sector, however, was largely spared the membership loss and 73 per cent of its workforce remained unionised. ${ }^{131}$

Chastened by the job losses associated with the 1981 recession, in February 1983 the ACTU signed an 'Accord' with the federal Labor Party, agreeing to a return to centralised wage fixation. In return, the Labor Party promised 'an industry development policy' to reinvigorate manufacturing. ${ }^{132}$ After the Hawke-Keating Labor government's election in March 1983, a return to centralised wage fixation followed. However, the new government adopted a neo-liberal agenda, floating the dollar, reducing tariffs and privatising government-owned enterprises. ${ }^{133} \mathrm{~A}$ manufacturing recovery was stifled and by 1986 only 15.5 per cent of the workforce was engaged in factory work. Such changes devastated many long-established unionised communities. At Wollongong, for example, 14,000 jobs were lost at the Port Kembla steel works between 1981 and 1984. In reflecting upon these changes, Lee and Hagan observe that these job losses 'did more than produce a temporary shock. It severely and chronically weakened the local trade union organisation, and it shook voters' confidence in the ability of a Labor government to protect their jobs' ${ }^{134}$ Such changes not only added to the steady disintegration of working-class communities, they also undercut what Taksa has called 'the norms of generalised reciprocity and social trust' between workers and their political representatives upon which labourism had built its support. ${ }^{135}$ While most unions continued their affiliation with the party, which in turn continued to draw recruits for parliamentary office from union ranks, Labor's embrace of free market principles left it without a clear guiding ideology.

Beset by far-reaching social and economic changes that were eroding its historic base, unionism was also threatened during the 1980s by the emergence of 'New Right' employer associations and think-tanks, such as the Business Council of Australia and the H.R. Nicholls Society. These bodies called for an end to arbitration. ${ }^{136}$ The ACTU argued that economic competitiveness was best enhanced by multi-skilling and revamped awards. ${ }^{137}$ The demands of both the ACTU and employers for 'reform' led to the gradual dismantling of Australia's arbitration system. In 1986, wage increases were made dependent on workers 'trading-off' award provisions. A year later 'award restructuring' commenced. In 1991 enterprise-based bargaining became the central focus of industrial relations. Non-union collective agreements followed in 1993. The election of the How ard coalition government in 1996 produced overtly anti-union legislation, including provisions for individual Australian Workplace 
Agreements. ${ }^{138}$ In 2005 the passage of the WorkChoices legislation revoked many union rights including ready access to workplaces where unions had coverage.

As industrial relations 'reform' gathered pace unionism went into a sharp decline. Between 1986 and 2008 union density fell from 45.6 to 18.9 per cent. Absolute membership fell from a peak of 2.7 million in 1990 to 1.7 million in 2008 . Unlike previous periods of decline the public sector was hard hit with union density falling by 28.7 percentage points to 41.9 percent between 1986 and 2008. A massive downsizing in the early 1990s, and a subsequent rebuilding with part-time workers, does much to explain this decline. It was in the private sector, however, that the marginalisation of union influence was most pronounced. By 2008, only 13.6 per cent of private sector workers held a union ticket.

In the wake of the dramatic post-1986 decline in union membership a wide body of research concurred that the union movement's long reliance on arbitration had had the effect of 'stultifying the development of workplace organisation'. ${ }^{139}$ It was also commonly held true that unions were less likely to lose members if workplaces had strong delegate structures in place - an opinion supported by workplace surveys in 1990 and 1995..$^{140}$ Not everyone, however, shared this view. Drago and Wooden argued that those who believed that a lack of workplace organisation caused union decline had confused cause and effect. The absence of union delegates was a result of union decline, they concluded, not its cause. ${ }^{141}$ What is nevertheless clear, as we have previously noted, is that workplace unionism was built upon arbitration. Few unions were prepared for arbitration's demise. Even the best organised suffered sharp membership falls. In the manufacturing sector only 21 per cent held a union ticket by 2009. In the coal industry, where unionism had won its initial mass following, union density fell from 85.2 per cent in 1996 to 46 per cent in August 2009.

If structural change in the economy had been the principal factor in union decline between 1954 and 1970, this was not the case after 1986. Union density fell away in every occupational group including, as we have just noted, mining and manufacturing - industries which had historically comprised industrial labour's strongest battalions. If labour market changes cannot, in themselves, explain accelerated union decline they nevertheless had a profound effect on the union movement's composition and strength. By 2006, manufacturing accounted for only ten per cent of all jobs. Employment in poorly-unionised industries increased. In 2009, retailing employed more workers than any other industry, providing jobs for more than one million workers. Yet only 15 per cent were unionised. Much of the growth in employment since 1986 has been in part-time, often casual work. Parttimers comprised 30 per cent of the workforce in 2009 compared to only 18 per cent in 1986. ${ }^{142}$ Only a handful (14.6 per cent) of these workers held a union ticket in 2009. The continued disappearance of blue-collar jobs also altered the union movement's gender balance. By 2009, women accounted for 47.2 per cent of all unionists. ${ }^{143}$ The feminisation of union ranks largely reflected their heavy representation in a number of industrial labour's few surviving strongholds - the public service, education and health.

Union decline also reflected deliberate anti-union employer strategies. This trend first became apparent in 1985 when unions suffered crushing defeats in the Queensland SEQEB dispute, at Dollar Sweets in Melbourne and at the Mudginberri meatworks. Employers in each instance were closely aligned with the emerging 


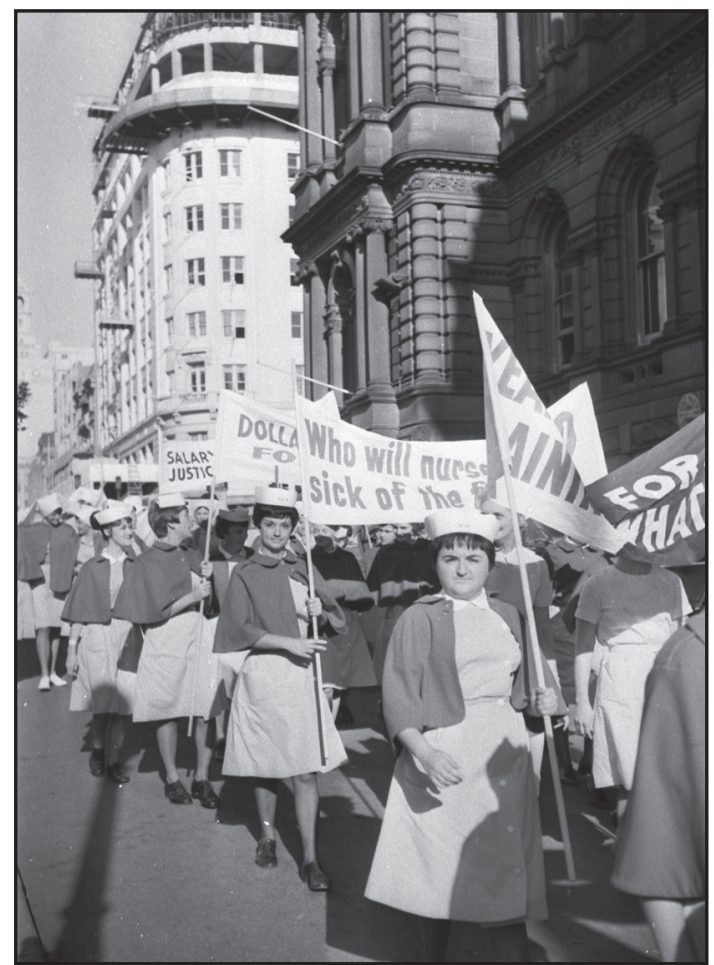

Protesting nurses outside Sydney's Town Hall

In 2009 females made up 47.2 per cent of the union movement's membership.

Courtesy: Mitchell Library, State Library of NSW. Call No. Government Printing Office 22137

New Right. ${ }^{144}$ In 1986, mining unions at Robe River suffered a crippling blow at the hands of CRA. The progressive deunionisation of the Western Australian iron ore industry ensued. ${ }^{145}$ By the mid-1990s employers were aggressively pursuing antiunion strategies in industries previously characterised by collaborative employerunion bargaining, including coal mining, road transport and the meat industry. ${ }^{146}$ The introduction of individual Australian Workplace Agreements gave employers a potent new weapon. At Telstra, for example, employees were encouraged to sign these individual agreements. Seventy per cent of those who did so resigned their union membership. ${ }^{147}$ Government support for anti-union strategies was manifest in the Patrick's dispute of 1998 when non-unionists replaced waterside workers. Unfortunately for the employer and the government, this particular dispute ended in a union victory. ${ }^{148}$

The union movement adopted two principal strategies to halt union decline. The first, enunciated in 1987, involved 'union rationalisation' whereby existing unions were encouraged to amalgamate into 20 'super' unions. ${ }^{149}$ This was a controversial proposal to which many unions were opposed. A number of studies suggested that, far from halting union decline, 'union rationalisation' alienated members. ${ }^{150}$ Research by Mark Wooden, however, found little evidence that amalgamations contributed to union decline. ${ }^{151}$ The ACTU's next strategy, Organising Works, had wider appeal. Adopted in 1994, its roots lay in the United States, where an 'organising model' was devised in the late 1980s and early 1990s to reinvigorate unionism. ${ }^{152}$ By the mid-1990s this model had become the cornerstone of union revival strategies throughout the Anglo-Saxon world. Its advocates argued that unions had contributed to their own decline by simply offering industrial services in return for a fee. This 'servicing model' 
encouraged membership passivity. The solution lay in a multi-dimension approach. There was a greater focus on recruitment. Through programs such as Organising Works a new generation of organisers was trained. Rank-and-file members were encouraged to take a more active role in solving workplace problems. Community engagement was also emphasised. ${ }^{153}$

It is difficult to assess the Australian success of the 'organising model'. Research by Cooper, Griffin and Moors, and Ellem highlight membership gains by both white and blue-collar unions, as well as in the Western Australian iron ore industry. ${ }^{154} \mathrm{~A}$ slow-down in union membership loss after 1999 has also been attributed to the 'organising model'. ${ }^{155}$ However, the decline in union density continued unabated until 2008. This may have been due to flaws in either the implementation of the 'organising model' or its design. ${ }^{156}$ Or it may simply reflect that no strategy could have fully offset the factors that conspired against unions under the Howard government. Yet, as the ACTU's Your Rights at Work campaign proved, the union movement could still show amazing powers of resilience. This campaign, waged against the Howard government's WorkChoices legislation, mobilised hundreds of thousands and was pivotal in the Rudd Labor government's election in November 2007. ${ }^{157}$ It would be hard to contradict the view that the activism inspired by the 'organising model' was a factor in these events.

Despite the union movement's best organising efforts there were wide swathes of the economy - notably hospitality, fruit picking, taxi driving and parts of the construction industry - where employers were able to avoid industrial regulation by recruiting workers who lacked the most basic protection enjoyed by Australian workers - citizenship. Many members of the shadow workforce that grew after 2000 were international students seeking to offset their living costs. Others were back-packers. By 2007, there were an estimated 500,000 such international visitors in the country engaged in some form of work. ${ }^{158}$ In addition to these workers were an unknown number who entered under false passports or who had overstayed their tourist visas. The tragic circumstances of many of these workers were poignantly demonstrated in the case of Myung Yeol Hwang, an illegal Korean immigrant who worked for 12 years in the Sydney construction industry without ever appearing on an employer's record book. Emaciated and starving, in desperation he approached the Construction Forestry Mining and Energy Union on 26 August 2010, only to die the following day. In the union's estimation, Mr Hwang's plight was 'symptomatic' of a wide-spread malaise within the building trade which involved thousands and possibly tens of thousands of illegal workers. ${ }^{159}$ Unlike previous ethnic minorities who entered the labour market at the bottom rung, such workers were denied award protection, being exposed to deportation if their circumstances became known.

Following the Rudd-Gillard government's passage of the Fair Work Act, a new industrial relations regime came into force in mid-2009. Enthusiasm among unionists was high and a rebound in membership was soon apparent. Absolute membership rose from 1,752,900 in August 2008 to 1,835,100 a year later. Most gains occurred in the public sector where union density rose from 41.9 to 46.3 per cent. Boosted by this strong performance, overall density rose from 18.9 to 19.7 per cent, thereby providing industrial labour with its first significant rebound since the 1970s. At the end of 2010, however, the continuation of this more favourable industrial relations environment hung by a thread. Federally, the Gillard government was returned 
in September 2010 without a clear mandate, being dependent for its survival on a motley alliance of urban Green-aligned politicians and rural Independents. In both New South Wales and Queensland unpopular Labor governments face eviction from office. In these circumstances, with uncertainty clouding the political horizon, the union movement's continued recovery rests primarily on its own shoulders.

\section{Conclusion}

The history of Australian unionism is not a single narrative. It is, instead, the product of countless stories with disparate beginnings and endings. The factors that underpinned the growth of unionism in Creswick, and which contributed to its demise, were different from those which shaped the fate of unionism in Midland, Junee, Casino or Rockhampton. Nor was it the case that, in forming unions, Australian workers always sought common objectives. Whereas some sought a defence of craft privilege some strived for socialism. Where some believed in the benefits of a White Australia others were committed to international solidarity. Yet, in forming unions, Australian workers did have one thing in common - the belief that they could gain more through collective action than they could by acting alone. The quandary for labour historians lies in ascertaining why there was both a marked upsurge in union membership in the four decades between 1880 and 1920 and a sustained loss of support for unionism in the 62 years after 1948. Clearly the effectiveness (or otherwise) of union-organising campaigns, the adoption of systems of compulsory arbitration, growing (or waning) community support for Labor, or even more radical political forces such as the Communist Party, all had an impact. But such factors only had social resonance when they had positive meaning in workers' lives. Considered on a broad historical canvas, industrial labour's rise and decline cannot therefore be properly accounted for without due regard to its social anchoring among the manual working class that emerged in the nation's mines, shearing sheds, factories, wharves and construction sites in the late-nineteenth century and which consistently made up two-thirds of the Australian labour force until the early 1950s. In the final analysis, unionism survived and grew because the members of this working class believed it delivered them a benefit. From the early 1950s, however, structural change in the economy brought about the gradual disintegration of the working-class constituency that had long championed unionism. By 1970 barely half the workforce belonged. After a series of recessions curtailed a brief rebound in union fortunes in the early 1970s, industrial labour found itself beset by new problems. From the 1980s industrial relations deregulation, a growth in precarious employment and employer anti-union strategies, as well as further structural changes in the economy, all combined to reduce industrial labour to the status of a minority movement, commanding the support of less than 20 per cent of wage and salary earners.

While union decline has now spanned three generations we should be wary of concluding that its condition is terminal. Industrial labour's death has been too often predicted. In 1938, for example, with the economy still suffering from the Great Depression's effects, Tim Moroney, the Queensland head of the Australian Railways Union, penned an introduction to Ernie Lane's forthcoming publication, Dawn to Dusk. Like Lane, Moroney was pessimistic about the fate of organised labour. 'Gone now', he wrote, 'is the fervid faith, the enduring enthusiasm, and the strong 
spirit of struggle that characterised the early Labour Movement'. ${ }^{160}$ But, despite his despair, Moroney confidently predicted that organised labour would 'rise again on the pressing economic and social needs of the workers'. ${ }^{161}$ Moroney's prediction was fulfilled as support for unionism reached new heights after World War II. Today, with the needs of countless workers still unfulfilled, a place for unionism remains.

Bradley Bowden is a labour historian currently employed as an Associate Professor within the Griffith Business School. His involvement with the union movement began in 1972 when, aged 17, he joined the AMIEU. In subsequent years, he worked as a factory worker and storemen and packer whilst studying at the University of Queensland. From 1980 to 1988, whilst employed as a merchant seamen, he belonged to the Seamens Union of Australia. He has published histories of three unions - the federal Transport Workers Union, Queensland's Bacon Factories Employees Union and the Queensland Branch of the United Firefighters Union. In 2009 he was the lead editor and principal contributor in Work and Strife in Paradise: The History of Labour Relations in Queensland, 1859-2009.

$<$ b.bowden@griffith.edu.au>

\section{Endnotes}

* The author wishes to thank the two anonymous referees who reviewed this article for their constructive criticism.

1. William Guthrie Spence, Australia's Awakening: Thirty Years in the Life of an Australian Agitator, Worker Trustees, Sydney and Melbourne, 1909, p. 11.

2. Ibid.

3. The 'dependency thesis' was first articulated by William Howard, see W.A. Howard, 'Australian trade unions in the context of union theory', Journal of Industrial Relations, vol. 19, no. 3, September 1977, pp. 255-73. Also W.A. Howard, 'Australian trade unions and the arbitration system', in Brian Head (ed.) State and Economy in Australia, Oxford University Press, Melbourne, 1983, pp. 238-51. Similar points have been made by Peter Fairbrother and Charlotte A.B. Yates, 'Unions in crisis, Unions in renewal?', in Peter Fairbrother and Charlotte A. B. Yates (eds), Trade Unions in Renewal: A Comparative Study, Continuum, London, 2003, pp. 1-31; David Peetz, Brave New Work Place, Allen \& Unwin, Sydney, 2006, pp. 161-62.

4. The trade union statistics cited in this paper are drawn from a series of Australian Bureau of Statistics surveys, notably Labour and Industrial Branch Reports, 1912-75 (ABS catalogue no. 6101.0); Trade Union Members, 1976-1996 (catalogue no. 6325.0) and Employee Earnings, Benefits and Trade Union Members, 1998-2008 (catalogue no. 6310.0). Unless otherwise stated, all other statistics cited in this paper are drawn from the extensive compendium of Australian labour statistics found as appendix to, Bradley Bowden, Simon Blackwood, Cath Rafferty and Cameron Allan (eds), Work and Strife in Paradise: The History of Labour Relations in Queensland 1859-2009, Federation Press, Sydney, 2009.

5. Ross M. Martin, Trade Unions in Australia, Penguin, Harmondsworth, 1975, p. 1. Also, Jim Hagan, The History of the A.C.T.U., Longman Cheshire, Melbourne, 1981, p. 1.

6. J.T. Sutcliffe, A History of Trade Unionism in Australia, Macmillan, Melbourne, 1967, p. 27.

7. Michael Quinlan, Margaret Gardner and Peter Akers, 'Formal organizing and informal associations among workers in the Australian colonies, 1795-1850', Labour/Le Travail, no. 53, Fall 2003, p. 160; G.J.R. Linge, Industrial Awakening: A Geography of Australian Manufacturing 1788 to 1890, ANU Press, Canberra, 1979, p. 100.

8. L.J. Hume, 'Working class movements in Sydney and Melbourne before the gold rushes', Historical Studies, vol. 9, November 1960, p. 266.

9. Greg Patmore, Australian Labour History, Longman Cheshire, Melbourne, 1991, pp. 36-38; Hume, 'Working class movements', pp. 266, 277; Michael Quinlan, Margaret Gardner and Peter Akers, 'A failure of voluntarism: shop assistants and the struggle to restrict trading hours in the colony of Victoria, 1850-85', Labour History, no. 88, May 2005, pp. 170-71; Tom O'Lincoln, United We Stand: Class Struggle in Colonial Australia, Red Rag Publications, Melbourne, 2006, pp. 9-28.

10. Hume, 'Working class movements', pp. 266-67.

11. Geoffrey Blainey, The Rush that Never Ended: The History of Australian Mining, $5^{\text {th }}$ edition, Melbourne University Press, Melbourne, 2003, p. 61.

12. A.C. Kelley, 'International migration and economic growth: Australia, 1865-1935', Journal of Economic History, vol. 25, no. 3, September 1965, pp. 333-54; Neville Hicks, ‘Demographic transition 
in the antipodes: Australian population structure and growth, 1891-1911', Australian Economic History Review, no. 14, 1974, pp. 123-42.

13. Evidence of Thomas Finney to Queensland Royal Commission into Factories and Shops, Queensland Votes and Proceedings, Queensland Government Printer, Brisbane, 1891, vol. 2, Question 1101.

14. E.W. O'Sullivan, 'New South Wales', in John Norton (ed.), The History of Capital and Labour in All Lands and Ages, Oceanic Publishing Co., Sydney and Melbourne, 1888, pp. 41-115; W.E. Murphy, 'Victoria', in Norton (ed.), History of Capital and Labour, pp. 16-98; Julie Kimber and Peter Love, 'The time of their lives', in Julie Kimber and Peter Love (eds), The Time of Their Lives: The Eight Hour Day and Working Life, Australian Society for the Study of Labour History, Melbourne, 2007, pp. 1-13; Also, Robin Gollan, Radical and Working Class Politics: A Study of Eastern Australia 18501910, Melbourne University Press, Carleton, 1960, pp. 70-76; Jeff Sparrow and Jill Sparrow, Radical Melbourne: A Secret History, Vulgar Press, Melbourne, 2001, p. 182. Also, Geoffrey Searle, The Golden Age: A History of the Colony of Victoria 1851-1861, Melbourne University Press, Melbourne, 1963, pp. 208-15; Helen Hughes, 'The eight hour day and the development of the labour movement in Victoria in the eighteen fifties', Historical Studies, vol. 9, no. 36, May 1961, pp. 396-412; Joe Harris, The Bitter Fight: A Pictorial History of the Australian Labor Movement, University of Queensland Press, St Lucia, 1970, pp. 23-25; Sutcliffe, Trade Unionism, pp. 4-42.

15. This argument found early exponents in, Sidney Webb and Harold Cox, Eight Hours Day, Walter Scott, London, 1891, p. 58.

16. W.E. Murphy, History of the Eight Hours Movement, Spectator Publishing Co., Melbourne, 1896, p. 80. Also, John Niland, 'The birth of the movement for a eight hour working day in New South Wales', Australian Journal of Politics and History, vol. 19, April 1968, p. 76; Bradley Bowden, "'Harmony ... between the employer and employed": Employer support for union formation in Brisbane, 1857-90', Labour History, no. 97, November 2009, pp. 105-22, at pp.108-110.

17. For in-depth discussions of the financial benefits for principal contractors in implementing shorter hours, see Bowden, 'Harmony ... between the employer and employed', pp. 108-11.

18. Jeff Rich, 'The traditions and significance of the eight hour day for building unionists in Victoria, 1856-90', in Kimber and Love (eds), Time of Their Lives, pp. 25-43.

19. General histories include T.G. Parsons, 'Learning the rules of the game: Some notes on the Labour Movement in the Melbourne manufacturing industries, 1870-1890', Journal of Australian Studies, vol. 6, June 1980, pp. 56-62; June Phillip, Trade Union Organisation in NSW and Victoria 18701890, unpublished MA thesis, University of Adelaide, 1953; Gollan, Radical and Working Class Politics, pp. 74-84; Brian Fitzpatrick, A Short History of the Australian Labor Movement, Second Edition, Macmillan, Melbourne, 1968, pp. 103-4; Sutcliffe, History of Trade Unionism, pp. 43-44; Jim Moss, Sound of Trumpets: History of the Labour Movement in South Australia, Wakefield Press, Adelaide, 1985, pp. 101-6; Bowden, 'Harmony ... between the employer and employed', pp. 10522; Quinlan, Gardner and Akers, Failure of Voluntarism, pp. 161-178. The histories of individual unions that embrace this period are, Ken Buckley, 'The Role of Labour: The Amalgamated Society of Engineers', Labour History, no. 4, May 1963, pp. 3-10; Ken Buckley, The Amalgamated Engineers in Australia 1850-1920, ANU Press, Canberra, 1970; J. Hagan, Printers and Politics, ANU Press, Canberra, 1966, pp. 37-52; Bradon Ellem, In Women's Hands: A History of Clothing Trades Unionism in Australia, NSW University Press, Sydney, 1989, pp. 22-24; Brian Fitzpatrick and Rowan Cahill, The Seamen's Union of Australia 1872-1972, Seamen's Union of Australia, Sydney, 1981, pp. 1-15.

20. Cathy Brigden, 'Creating labour's space: The case of the Melbourne Trades Hall', Labour History, no. 89, November 2005, pp. 125-40; Raymond Markey, In Case of Oppression: The Life and Times of the Labor Council of New South Wales, Pluto Press, Leichhardt, 1994, pp. 9-29; Raymond Markey, 'The Labor Council of New South Wales: 1871-2001', in Bradon Ellem, Raymond Markey and John Shields (eds), Peak Unions in Australia: Origins, Purpose, Power, Agency, Federation Press, Sydney, 2004, pp. 54-57.

21. Markey, In Case of Oppression, p. 9.

22. Rachael Henning, The Letters of Rachael Henning, edited by David Adams, Penguin, Harmondsworth, 1977, p. 208.

23. Bowden, 'Harmony ... between the employer and employed', p. 113. Spence notes that: 'Quite a number of attempts' were made to organise shearers 'prior to 1886, but all had failed'. See Spence, Australia's Awakening, p. 68.

24. See J.W. Turner, Coal Mining in Newcastle 1801-1900, Newcastle City Council, 1982, p. 89. Also, Robin Gollan, The Coalminers of New South Wales, ANU Press, Canberra, 1963, pp. 27-64; Bradley Bowden, 'The Hunter', in Jim Hagan (ed.), People and Politics in Regional New South Wales,

Federation Press, 2006, pp. 53-60.

25. Blainey, The Rush that Never Ended, pp. 302, 123; June Stoodley, 'Queensland miners' attitudes towards the need for safety regulation in the late nineteenth century', Labour History, no. 14, May 1968, pp. 23-33.

26. Spence, Australia's Awakening, pp. 24-33

27. The reasoning behind the 20 per cent estimate is discussed in a footnote in, Gollan, Radical and Working Class Politics, p. 133. Markey estimates that in 1891 union density in New South Wales was 21.5 per cent. See Ray Markey, The Making of the Labor Party in New South Wales, 1880-1900, New 
South Wales University Press, Sydney, 1988, pp. 139-40.

28. John Norton, 'Introduction', in Norton (ed.), The History of Capital and Labour, p. ix.

29. N.G. Butlin, Investment in Australian Economic Development 1861-1900, Cambridge University Press, Melbourne, 1964, pp. 3-7; N.G. Butlin, 'Some perspectives of Australian economic development', in C. Forster, Australian Economic Development in the Twentieth Century, Allen \& Unwin, Sydney, 1970, p. 291, table 6.10 .

30. For discussions of union organisation among female workers at this time, see Raymond Brooks, 'The Melbourne Tailoresses' strike: An assessment', Labour History, no. 44, May 1983, pp. 27-38; Danielle Thornton, "“We have no redress unless we strike": Class, gender and activism in the Melbourne tailoresses' strike, 1882-83', Labour History, no. 96, May 2009, pp. 19-38; W. McNicol, 'Women and the trade union movement in New South Wales', Labour History, no. 36, May 1979, pp. 18-30; Raelene Frances, Politics of Work: Gender and Labour in Victoria, 1880-1939, Cambridge University Press, Melbourne, 1993 pp. 35-37, 56; Raelene Frances, '“No more amazons”: Gender and work process in the Victorian clothing trades, 1930-1939', Labour History, no. 50, May 1986, pp. 95-112; Bradley Bowden and Toni Bowden, "“Women do the machinery": Craft, gender and work transformation in the Brisbane boot trade, 1869-95', Labour History, no. 86, May 2004, pp. 75-92; Ellem, In Women's Hands, pp. 28-32; Andrew Spaull and Martin Sullivan, A History of the Queensland Teachers' Union, Allen \& Unwin, Sydney, 1989, pp. 27-64.

31. John Merritt, The Making of the AWU, Oxford University Press, Melbourne, 1987, p. 138; H. Kenway, 'The Pastoral Strikes of 1891 and 1894', in D.J. Murphy, R.B. Joyce and Colin A. Hughes, Prelude to Power: The Rise of the Labor Party in Queensland 1885-1915, Jacaranda Press, Milton, 1970, p. 123.

32. Butlin, Investment in Australian Economic Development, pp. 60-80.

33. Bradon Ellem and John Shields, 'Making the "Gibraltar of unionism": Union organising and peak agency in Broken Hill, 1886-1930', Labour History, no. 83, November 2002, pp. 65-88; Blainey, The Rush that Never Ended, p. 300.

34. Gollan, Radical and Working Class Politics, pp. 80-81; Markey, In Case of Oppression, p. 23.

35. The establishment of colonial labour councils is discussed in the collection of essays in, D. J. Murphy (ed.), Labor in Politics: The State Labor Parties in Australia 1880-1920, University of Queensland Press, St Lucia, 1975. For the histories of individual labour councils see, Bobbie Oliver, Unity is Strength: A History of the ALP and the Trades and Labor Council in Western Australia, 1899-1999, API Network, Perth, 2003; John Kellett, 'Product of a Community in Transition: The first Brisbane Trades and Labour Council', in Ellem, Markey and Shields (eds), Peak Unions in Australia, pp. 86-111; Moss, Sound of Trumpets.

36. For an overview of the changes that led to increased union organisation see, Ray Markey, 'Explaining union mobilisation in the 1880s and early 1900s', Labour History, no. 83, November 2002, pp. 19-42; Markey, The Making of the Labor Party, pp. 136-70; Gollan, Radical and Working Class Politics, pp. 99-127.

37. For an overview of division's within industrial labour see, Ken Buckley and Ted Wheelwright, No Paradise for Workers: Capitalism and the Common People in Australia 1788-1914, Oxford University Press, Melbourne, 1988, pp. 140-63.

38. T.M. McGregor, 'Letter to Editor', Worker, 15 November 1890

39. Bruce Scates, A New Australia: Citizenship, Radicalism and the First Republic, Cambridge University Press, Melbourne, 1997, p. 51.

40. Gollan, Radical and Working Class Politics, pp. 110-27; Scates, A New Australia, pp. 8-9; Bruce Scates, "'Millenium or pandemonium?": Radicalism in the labour movement, Sydney, 1889-1899', Labour History, no. 50, May 1986, pp. 72-94; John Kellett, 'William Lane and "New Australia": A reassessment', Labour History, no. 72, May 1997, pp. 1-18.

41. Peter Love, Labour and the Money Power: Australian Labour Populism 1890-1950, Melbourne University Press, Melbourne, 1984, p. 36; Scates, A New Australia, p. 9; John Rickard, Australia: A Cultural History, $2^{\text {nd }}$ edition, Longman, London, 1996, p. 143.

42. Gollan, Radical and Working Class Politics, pp. 110-27; Scates, A New Australia, pp. 6-7; Love, Labour and the Money Power, pp. 20-55; Verity Burgmann, 'In Our Time': Socialism and the Rise of Labor 18851905, Allen \& Unwin, Sydney, 1985; Spence, Australia's Awakening, pp. 268-70; Ernie Lane, Dawn to Dusk: Reminiscences of a Rebel, SHAPE, Brisbane, 1993, pp. 54-99.

43. Bede Nairn, Civilising Capitalism: The Beginnings of the Australian Labor Party, Melbourne University Press, Melbourne, 1989, pp. 5-8; D.J. Murphy, 'Queensland', in Labor in Politics: The State Labor Parties in Australia 1880-1920, University of Queensland Press, St Lucia, 1975, p. 129; J.B. Dalton, The Queensland Labour Movement 1889-1915, unpublished BA Hons. thesis, University of Queensland, 1961, Conclusion, p. 1; J.B. Dalton, 'An interpretative survey: The Queensland labour movement', in D.J. Murphy, R.B. Joyce and Colin A. Hughes (eds), Prelude to Power: The Rise of the Labour Party in Queensland 1885-1915, Jacaranda Press, Milton, 1970, pp. 5-7.

44. Burgmann, In Our Time, p. 1.

45. Butlin, Investment in Australian Economic Development, p. 390; R.V. Jackson, Australian Economic Development in the Nineteenth Century, ANU Press, Canberra, 1977; Sean Glynn, Urbanization in Australian History 1788-1900, Nelson, Melbourne, 1975; Eric Fry, The Condition of the Urban WageEarning Class in Australia in the 1880s, unpublished PhD thesis, Australian National University, 1956. 
46. S.H. Fisher, 'An Accumulation of misery?', Labour History, no. 40, May 1981, pp. 16-28; Shirley Fitzgerald, Rising Damp: Sydney 1870-1890, Oxford University Press, Melbourne, 1982; Max Kelly, A Certain Sydney, Doak Press, Sydney, 1978; Michael Cannon, Australia in the Victorian Age, 3 volumes, Nelson, Melbourne, 1971, 1975, 1978; Alan Mayne, 'City back-slums in the land of promise: Some aspects of the 1876 report on over-crowding in Sydney', Labour History, no. 38, May 1980, pp. 26-39.

47. J. Lee and C. Fahey, 'A boom for whom? Some developments in the Australian labour market 18701891', Labour History, no. 50, May 1986, pp. 1-27; Markey, The Making of the Labor Party, pp. 49-51; Patmore, Australian Labour History, p. 140.

48. Hagan, Printers and Politics, pp. 40, 66, 148, 169; Markey, The Making of the Labor Party, pp. 50-51.

49. Bradley Bowden, "“Some mysterious terror": The relationship between capital and labour in Ipswich, 1861-96', Labour History, no. 72, May 1997, pp. 77-100.

50. The issue of transience and its impact is explored in Bradley Bowden, 'Transience, class and community', Labour History, no. 77, November 1999, pp. 160-89.

51. For a discussion of racism and the labour movement see the collection of articles in, Ann Curthoys and Andrew Markus (eds), Who are Our Enemies? Racism and the Working Class in Australia, Hale \& Iremonger, Sydney, 1978; Humphrey McQueen, A New Britannia, Penguin, Ringwood, 1970, ch. 2; Andrew Markus, 'Explaining the treatment of non-European immigrants in nineteenth century', Labour History, no. 48, May 1985, pp. 86-91; Patmore, Australian Labour History, pp.184-208.

52. Shirleene Robinson, 'The unregulated employment of Aboriginal children in Queensland', Labour History, no. 82, May 2002, pp. 1-16.

53. Raymond Evans, Kay Saunders and Kathryn Cronin, Race Relations in Colonial Queensland, University of Queensland Press, St Lucia, 1975, p. 216.

54. Mark Hearn and Harry Knowles, One Big Union: A History of the Australian Workers Union 18861994, Cambridge University Press, Melbourne, 1996, pp. 66-67.

55. E.A. Boehm, Twentieth Century Economic Development in Australia, $2^{\text {nd }}$ Edition, Longman Cheshire, Melbourne, 1979, pp. 74-75, table 3.111.

56. In all colonies the exact union strength is unknown due to the failure of most bodies to register with the Trade Union Registrar. In Queensland, for example, the officially recorded union strength in 1898 was a mere 490. See Murphy, Joyce and Hughes (eds), Prelude to Power, appendix H.

57. Ellem and Shields, 'Making the "Gibraltar of unionism"', p. 69.

58. H.J. Gibney, 'Western Australia', in Murphy (ed.), Labor in Politics, p. 347. Also see the series of articles on the Western Australian goldfields in Labour History, no. 65, November 1993.

59. Spence, Australia's Awakening, p. 111.

60. Vere Gordon Childe, How Labour Governs, Melbourne University Press, $2^{\text {nd }}$ edition, Melbourne, 1964, p. 12.

61. John Rickard, Class and Politics: New South Wales, Victoria and the Early Commonwealth, 1890-1910, ANU Press, Canberra, 1976, pp. 50, 119, 293.

62. Worker, 19 November 1892

63. Gollan, Radical and Working Class Politics, pp. 185-86; Hagan, History of the A.C.T.U., p. 8.

64. Ray Markey, 'Trade unions, the Labor Party and the introduction of arbitration in New South Wales and the Commonwealth', in Stuart Macintyre and Richard Mitchell (eds), Foundations of Arbitration: The Origins and Effects of State Compulsory Arbitration 1890-1914, Oxford University Press, Melbourne, 1989, p. 166.

65. For a succinct overview of the Australian arbitration system, see J.J. Portus, Australian Compulsory Arbitration 1900-1970, Hicks Smith \& Sons, Sydney, 1971.

66. Howard, 'Australian trade unions in the context of union theory', pp. 260-61, 255. Also Howard, 'Australian trade unions and the arbitration system', pp. 238-51.

67. Rae Cooper, "“To organise whenever the necessity exists": The activities of the Organising Committee of the Labor Council of NSW, 1900-1910', Labour History , no. 83, November 2002, p. 51; Markey, 'Explaining union mobilisation', pp. 27-31; Rae Cooper, Making the NSW Union Movement? A Study of Organising and Recruitment Activities of the NSW Labor Council 1900-1910, Industrial Relations Research Centre, University of New South Wales, 1996.

68. Peter Sheldon, 'Arbitration and union growth: Building and construction unions in NSW, 1901-1912', Journal of Industrial Relations, vol. 35, no. 3, pp. 379-97; Peter Sheldon, 'Compulsory arbitration and union recovery: Maritime-related unions', Journal of Industrial Relations, vol. 40, no. 3, September 1998, pp. 422-40; Peter Sheldon, 'The missing nexus? Union recovery, growth and behaviour during the first decades of arbitration: Towards a Re-evaluation', Australian Historical Studies, no. 104, April 1995, pp. 415-37.

69. Colin Forster, 'The economy, wages and the establishment of arbitration', in Macintyre and Mitchell (eds), Foundations of Arbitration, p. 216.

70. Andrew Wells, 'State regulation for a moral economy: Peter Macarthy and the meaning of the Harvester Judgement', Journal of Industrial Relations, vol. 40, no. 3, September 1998, pp. 371-82.

71. Bradley Bowden, Driving Force: The History of the Transport Workers Union of Australia 1883-1992, Allen \& Unwin, Sydney, 1993, pp. 37-38.

72. Margo Beasley, The Missos: A History of the Federated Miscellaneous Workers Union, Allen \& Unwin, Sydney, 1996, pp. 3-5. 
73. Commonwealth Statistician, Labour and Industrial Branch Report, 1921, Commonwealth Government, 1922, p. 12

74. Commonwealth Arbitration Reports, vol. 2, p. 16 (ie 2 CAR 16)

75. 6 CAR 61

76. Cited Frances, Politics of Work, p. 91

77. Commonwealth Bureau of Census and Statistics, Labour and Industrial Branch Report No. 3, Commonwealth Government, Melbourne, 1914, p. 13.

78. Hagan, History of the A.C.T.U., p. 14. The strongest critique of Hagan's definition is found in Terry Irving, 'Labourism: A political genealogy', Labour History, no. 66, May 1994, pp. 1-13. Ray Markey summaries the debates that have emerged around the concept of labourism in Ray Markey, 'An Antipodean phenomenon: Comparing the Labo(u)r Party in New Zealand and Australia', Labour History, no. 95, November 2008, p. 82 .

79. Rickard, Australia, p. 141.

80. Rickard, Class and Politics, pp. 109-10.

81. Michael Quinlan and Constance Lever-Tracey, 'From labour market exclusion to industrial solidarity: Australian trade union responses to Asian workers, 1830-1988', Cambridge Journal of Economics, vol. 14, 1990, pp 168-69.

82. Lucy Taksa, 'Workplace, community, mobilisation and labour politics at the Eveleigh Railway Workshops', in Raymond Markey (ed ), Labour and Community: Historical Essays, University of Wollongong Press, Wollongong, 2001, pp. 51-79; Lucy Taksa, 'Politics, industrial heritage and working life at Eveleigh', Labour History, no. 85, November 2003, pp. 65-88; Patrick Bertola and Bobbie Oliver, The Workshops: A History of the Midland Railway Workshops, University of Western Australia Press, Perth, 2006; Janet McCalman, Struggletown: Portrait of an Australian Working-Class Community 1900-1965, Penguin, Ringwood, 1984; Colin Cleary, Bendigo Labor: The Maintenance of Traditions in a Regional City, Colin Cleary, Epson, 1999; Greg Patmore, 'Localism and labour: Lithgow 1869-1932', Labour History, no. 78, May 2000, pp. 53-70; Greg Patmore, 'Union birth, growth and death: The impact of the state, management and community at the Lithgow Ironworks', Journal of Industrial Relations, vol. 46, no. 1, pp. 21-38; Bradon Ellem and John Shields, 'Making a "union town": Class, gender and consumption in inter-war Broken Hill', Labour History, no. 78, May 2000, pp. 116-40; Bradley Bowden, 'A "time the like of which was never before experienced": Changing community loyalties in Ipswich, 1900-12', Labour History, no. 78 May 2000, pp. 71-93; Barbara Webster, 'A “cosy relationship" if you had it: Queensland Labor's arbitration system and union organising strategies in Rockhampton, 1916-57', Labour History, no. 83, November 2002, pp.89-106; Barbara Webster, "“The best deal for workers": Rockhampton unions and the Queensland arbitration system to 1957', in Bowden et al., Work and Strife in Paradise, pp. 202-17.

83. Taksa, 'Workplace, community, mobilisation and labour politics', pp. 60-61.

84. McCalman, Struggletown, p. 37.

85. Hearn and Knowles, One Big Union, pp. 127, 110.

86. Jim Hagan and Ken Turner, A History of the Labor Party in New South Wales 1891-1991, Longman Cheshire, Melbourne, 1991, p. 42.

87. P.G. Macarthy, The Harvester Judgement: An Historical Assessment, unpublished PhD thesis, Australian National University, 1967, p. 25.

88. For a general discussion of the IWW's influence see, Ian Turner, Industrial Labour and Politics, Hale \& Iremonger, Sydney, 1907, pp. 55-67. Also Childe, How Labour Governs, pp. 104-81; Verity Burgmann, Revolutionary Industrial Unionism: The Industrial Workers of the World in Australia, Cambridge University Press, Melbourne, 1995.

89. Hagan, History of the A.C.T.U., pp. 18-25

90. Childe, How Labour Governs, p. 11

91. The employment figures cited in this section are drawn from, Boehm, Twentieth Century Economic Development, pp. 74-75, table 3.111.

92. Tom Sheridan, Mindful Militants: The Amalgamated Engineering Union if Australia 1920-1972, Cambridge University Press, Melbourne, 1975, p. 13.

93. Commonwealth Statistician, Labour and Industrial Branch Report, 1921, p. 12.

94. Rickard, Australia, p. 180.

95. The limited opportunities in working class communities are vividly portrayed in McCalman, Struggletown.

96. Boehm, Twentieth Century Economic Development, p. 191

97. For a fuller discussion of Queensland developments see Bradley Bowden, 'A peculiar history: Queensland unions, 1916-2009', in Bowden et al., Work and Strife, pp. 43-44.

98. See, for example, Tom Bramble, Trade Unionism in Australia: A History from Flood to Ebb Tide, Cambridge University Press, Melbourne, 2008, p. 17; Howard, 'Australian trade unions in the context of union theory', pp. 266-67; Howard, 'Australian trade unions and the arbitration system', p. 245.

99. Rae Cooper and Greg Patmore, 'Trade union organising and labour history', Labour History, no. 83, November 2002, p. 14

100. Barbara Webster, 'Fighting in the Grand Cause': A History of the Trade Union Movement in 
Rockhampton 1907-1957, unpublished PhD thesis, University of Central Queensland, 1999; Webster, 'A cosy relationship', pp. 89-106; Webster, 'The best deal for workers', pp. 202-17.

101. Bertola and Oliver (eds), The Workshops.

102. Lenore Layman, 'Labour organisation: An industrial stronghold for the unions', in Bertola and Oliver (eds), The Workshops, p. 178. Sandra Cockfield, whose work draws on studies of three large-scale metal shops, also argues that 'the role of arbitration in limiting the need for worker mobilisation ... should not be overstated'; see Sandra Cockfield, 'Mobilising at the workplace: State regulation and collective action in three workplaces, 1900 to the 1920s', Labour History, no. 93, November 2007, pp. 35-56.

103. Hagan, History of the A.C.T.U., pp. 81-85.

104. For discussion of the role of women in the war-time economy, see Penny Ryan and Tim Rowse, 'Women, arbitration and the family', in Ann Curthoys, Susan Eade and Peter Spearritt (eds), Women at Work, Australian Society for the Study of Labour History, Canberra, 1975, pp. 15-30; Constance Larmour, 'Women's wages and the WEB', in Curthoys, Eade and Spearritt (eds), Women at Work, pp. 47-58; Glenda Strachan, 'Women's pay and participation in the Queensland workforce', in Bowden et al., Work and Strife in Paradise, pp153-55; Carolyn Allport, 'Left off the agenda: Women, reconstruction and new order housing', Labour History, no. 46, May 1984, pp. 1-20.

105. The most significant histories of the CPA are, W.J. Brown, The Communist Movement and Australia: An Historical Outline, 1890s to 1980s, Australian Labor Movement History Publications, Haymarket, 1986; Alastair Davidson, The Communist Party of Australia: A Short History, Hoover University Press, Stanford, 1969; Tom O'Lincoln, Into the Mainstream: The Decline of Australian Communism, Stained Wattle Press, Sydney, 1985; Stuart Macintyre, The Reds: The Communist Party of Australia from origins to illegality, Allan \& Unwin, St Leonards, NSW, 1998. For a recent addition to the literature see, Philip Deery and Neil Redfern, 'No lasting peace? Labor, communism and the Cominform: Australia, and Great Britain', Labour History, no. 88, May 2005, pp. 63-86. The estimates of communist strength among unionists is drawn from Davidson, The Communist Party, p. 92

106. Queensland Government Industrial Gazette, Government Printer, Brisbane, 1946, pp. 1063-64.

107. Interview of B.A. Santamaria with author, September 1990.

108. There is an extensive historiography on the Movement and the subsequent 'Split'. Key studies include Robert Murray, The Split: Australian Labor in the Fifties, Cheshire, Melbourne, 1970; B. A. Santamaria, Against the Tide, Oxford University Press, Melbourne, 1981; Jack Kane, Exploding the Myths: The Political Memoirs of Jack Kane, Angus \& Robertson, Sydney, 1989; Susanna Short, Laurie Short: A Political Life, Allen \& Unwin, North Sydney, 1992; F.G. Clarke, 'Labour and the Catholic Social Studies Movement', Labour History, no. 20, May 1971, pp. 46-59; Doug Blackmur, 'The ALP industrial groups in Queensland', Labour History, no. 46, May 1984; D.J. Murphy, 'The 1957 Split', in D.J. Murphy, R.B. Joyce and Colin A. Hughes (eds), Labor in Power, University of Queensland Press, St Lucia, 1980, pp. 481-525; Barbara Webster, "'To fight against the horrible evil of Communism": Catholics, community and the Movement in Rockhampton, 1943-57', Labour History, no. 81, November 2001, pp. 155-73.

109. Hagan, History of the A.C.T.U., p. 128; L.F. Crisp, Ben Chifley, Longmans, Melbourne, 1961, p. 360; Murray, The Split, p. 21.

110. Tom Sheridan, Division of Labour: Industrial Relations in the Chifley Years, 1945-49, Oxford University Press, Melbourne, 1989, pp. 248-90; Phillip Deery, The 1949 Coal Strike, unpublished PhD thesis, La Trobe University, 1976; Phillip Deery, 'Chifley, the army and the 1949 coal strike', Labour History, no. 68, May 1995, pp. 80-97. Also see the documentary collection, Phillip Deery (ed.), Labour in Conflict: The 1949 Coal Strike, Occasional Publication, Australian Society for the Study of Labour History, 1978.

111. Gollan, The Coalminers, pp. 234-35, 240.

112. Boehm, Twentieth Century Economic Development, p. 75, table 3.11

113. Bramble, Trade Unionism in Australia, p. 240.

114. The union density figure published in Labour and Industrial Branch Reports (ABS catalogue no. 6101.0) was for 50 per cent. However, this figure was subsequently revised in 1979 to 49 per cent. See Trade Union Members (ABS catalogue no. 6325.0), 1979.

115. For figures relating to waterside workers in Cairns, see Ross Fitzgerald, From 1915 to the Early 1980s: A History of Queensland, University of Queensland Press, St Lucia, 1984, pp. 199-200. Figures for unionised factory workers were based on Labour Report (ABS catalogue no. 6101.0), no. 44, 1955-56, p. 152; no. 55, 1970, p. 283.

116. Gerard Griffin, 'White collar unionism 1969 to 1981: Some determinants of growth', Journal of Industrial Relations, vol. 25, no. 1, March 1983, p. 27. An early but still useful analysis of the growth in white-collar unionism is Rees D. Williams, "White collars" make council', Labour History, no. 6, May 1964, pp. 29-37.

117. Griffin, 'White collar unionism', p. 30

118. D.W. Rawson, Unions and Unionists in Australia, Allen \& Unwin, Sydney, 1978, p. 39.

119. Russell Lansbury, 'The growth and unionisation of white-collar workers in Australia: Some recent trends', Journal of Industrial Relations, 1977, vol. 19, no. 1, p. 44.

120. Griffin, 'White collar unionism', pp. 32-33.

121. Griffin, 'White collar unionism', pp. 26-27. 
122. Lansbury, 'The growth and unionisation of white-collar workers', pp. 44-45.

123. Quinlan and Lever-Tracey, 'Labour market exclusion', pp. 171-72.

124. Commonwealth of Australia, Census of 2006, www.censusdata.abs.gov.au

125. Quinlan and Lever-Tracey, 'Labour market exclusion', pp. 170-78.

126. For a detailed discussion of the wage campaigns of this era see, Bowden, Driving Force, pp. 128-73.

127. Carol O'Donnell and Philippa Hall, Getting Equal: Labour Market Regulation and Women's Work, Allen \& Unwin, Sydney, 1988, p. 54; Edna Ryan and Anne Conlon, Gentle Invaders: Australian Women at Work, $2^{\text {nd }}$ edition, Penguin, Melbourne, 1989, p. 192; Strachan, 'Women's pay and participation', p. 156; Tom Sheridan and Pat Stretton, 'Pragmatic procrastination: Government, unions and equal pay, 1949-68', Labour History, no. 94, May 2008, pp. 133-56.

128. For a detailed discussion of aboriginal workers in labour history see the special edition, Labour History, no. 69, November 1995. For discussions of the Green Bans movement, see Verity Burgmann, 'The Green Bans Movement: Workers' power and ecological radicalism in Australia in the 1970s', Journal for the Study of Radicalism, 2008, vol. 2, no. 1, pp. 63-90; Meredith Burgmann and Verity Burgmann, Green Bans, Red Union: Environmental Activism and the New South Wales Builders Labourers' Federation, University of New South Wales Press, Sydney, 1998; Pete Thomas, Taming the Concrete Jungle: The Builders Laborers Story, Builders Laborers Federation, Sydney, 1973.

129. For a detailed discussion of the factors underpinning the crisis of manufacturing see, Jenny Stewart, The Lie of the Level Playing Field: Industry Policy and Australia's Future, Text Publishing Co., Melbourne, 1994, pp. 74-88.

130. Bowden, Driving Force, pp. 171-73.

131. Australian Bureau of Statistics, Labour Statistics, (catalogue no.6101.0), Canberra, 1982, p. 131. Note: changes in the method of collecting union statistics mitigates against direct comparison with pre1976 figures. Earlier figures were based on union membership lists. Latter figures were based on household surveys.

132. 'Statement of Accord by the Australian Labor Party and the Australian Council of Trade Unions regarding economic policy', in Frank Stilwell, The Accord ... and Beyond, Pluto Press, Sydney, 1986, appendix A.

133. For an overview of these events, see Stilwell, The Accord. For a recent addition, see Joe Collins and Drew Castle, 'Labor neoliberals or pragmatic neo-Laborists? The Hawke and Keating Labor Governments in Office, 1983-1996', Labour History, no. 98, May 2010, pp. 25-38.

134. Henry Lee and Jim Hagan, 'The Illawarra', in Jim Hagan (ed.), People and Politics in Regional New South Wales: The 1950s to 2006, Federation Press, Sydney, 2006, p. 100.

135. Taksa, 'Workplace, community, mobilisation and labour politics', p. 58.

136. For studies of the impact of employer associations on industrial relations change in this era, see Peter Sheldon and Louise Thornthwaite (eds), Employer Associations and Industrial Relations Change: Catalysts or Captives? Allen \& Unwin, Sydney, 1999. For a recent addition, see Damien Cahill, 'Business mobilisation, the New Right and Australian Labor Governments in the 1980s', Labour History, no. 98, May 2010, pp. 7-24.

137. Australian Council of Trade Unions/Trade Development Commission, Australia Reconstructed, Economic Planning Advisory Council, Canberra, 1987.

138. For an overview of these changes, see Braham Dabscheck, 'The slow and agonising death of the Australian experiment with conciliation and arbitration', Journal of Industrial Relations, vol. 43, no. 3, pp. 277-93. Also, for the period prior to 1996, Braham Dabscheck, The Struggle for Australian Industrial Relations, Oxford University Press, Melbourne, 1995.

139. Michael Alexander, Roy Green and Andrew Wilson, 'Delegate structures and strategic unionism: Analysis of factors in union resilience', Journal of Industrial Relations, vol. 40, no. 4, December 1998, p. 665. For similar views, see David Peetz, Barbara Pocock and Chris Houghton, 'Organisers' roles transformed? Australian union organisers and changing union strategy', Journal of Industrial Relations, vol. 49, no. 2, April 2007; p. 151; David Peetz, Unions in a Contrary World: The Future of the Australian Trade Union Movement, Cambridge University Press, Melbourne, 1998, p. 120; Peetz, Brave New Work Place, p. 161; Fairbrother and Yates, 'Unions in crisis', pp. 6-7; Bramble, Trade Unionism in Australia, p. 14; Barbara Pocock, 'Institutional sclerosis: Prospects for trade union transformation', Labour \& Industry, vol. 9, no. 1, April 1998, pp. 24-25.

140. Alexander, Green and Wilson, 'Delegate structures and strategic unionism', pp. 663-89; Peetz, Brave New Work Place, pp. 164-65; David Peetz, Why Join? Why Stay? Instrumentality, Beliefs, Satisfaction and Individual Decisions on Union Membership, Discussion Paper no. 356, Centre for Economic Policy Research, Australian National University, Canberra, 1997; Gerard Griffin and Stuart Svensen, 'The decline of Australian union density: A survey of the literature', Journal of Industrial Relations, vol. 38, no. 4, December 1996, pp. 505-47. The major surveys were, Ron Callus, Alison Morehead, Mark Cully and John Buchanan, Industrial Relations at Work: The Australian Workplace Industrial Relations Survey, Australian Government Printing Service, Canberra, 1991; Alison Morehead, Mairi Steele, Malcolm Alexander, Kerry Stephen and Linton Duffin, Changes at Work: The 1995 Australian Workplace Industrial Relations Survey, Longman, Melbourne, 1997.

141. Robert Drago and Mark Wooden, The Changing Role of Trade Unions in Australian Workplace Industrial Relations, Discussion Paper Series no. 3, National Institute of Labour Studies, Adelaide, 1998, p. 55. 
142. Ian Castles, Australian Social Trends, 1994: Trends in Trade Union Membership, Australian Bureau of Statistics, Canberra, 1995, table 3; Employee Earnings, Benefits and Trade Union Members (ABS catalogue no. 6310.0), August 2009, p. 28.

143. Employee Earnings, Benefits and Trade Union Members (ABS catalogue no. 6310.0), August 2009, pp. 31-34.

144. Dabscheck, Struggle for Australian Industrial Relations, pp. 30-31; Jim Kitay and Rod Power, 'Exploitation at \$1000 per week? The Mudginberri dispute', Journal of Industrial Relations, vol. 29, no. 3, September 1987, pp. 365-400; Simon Blackwood, ‘Doomsday for the Queensland labour movement: The SEQEB dispute and union strategy', Politics, vol. 24, no. 1, 1999, pp. 68-96.

145. Bruce Hearn Mackinnon, 'CRA/Rio Tinto in the 1990s: A decade of deunionisation', Labour History, no. 97, November 2009, pp. 75-96.

146. Michael Barry, 'Employer associations in coal mining', in Sheldon and Thornthwaite (eds), Employer Associations, pp. 134-36; Michael Barry and Peter Waring, “"Shafted”: Labour productivity and Australian coal miners', Journal of Australian Political Economy, vol. 44, December 1999, pp. 89-112; Bradley Bowden, 'Employer associations in road transport', in Sheldon and Thornthwaite (eds), Employer Associations, pp. 106-13; Patrick O'Leary and Peter Sheldon, 'Employer militancy in Victoria's meat industry, 1986-93', Labour History, no. 95, November 2008, pp. 223-42. For an overview of anti-union strategies in Australian labour history, see Rae Cooper and Greg Patmore, 'Private detectives, blacklists and company unions: Anti-union employer strategy and Australian labour history', Labour History, no. 97, November 2009, pp. 1-11.

147. Rae Cooper, Bradon Ellem, Chris Briggs and Dianne van den Broek, 'Anti-unionism, employer strategy, and the Australian state, 1996-2005', Labor Studies Journal, vol. 34, no. 3, September 2009, pp. 339-62.

148. For a comprehensive history of the dispute, see Helen Trinca and Anne Davies, Waterfront: The Battle that Changed Australia, Doubleday/Random House, Sydney, 2000.

149. Australian Council of Trade Unions, Future Strategies for the Trade Union Movement, Australian Council of Trade Unions, Melbourne, 1987.

150. Dabscheck, Struggle for Australian Industrial Relations, p. 135; Michael Costa and Michael Duffy, Labor, Prosperity and the Ninties: Beyond the Bonsai Economy, Federation Press, Sydney, 1991, p. 107; Barbara Pocock, 'Trade unionism in 1995', Journal of Industrial Relations, vol. 38, no. 1, March 1996, p. 132.

151. Mark Wooden, 'Union amalgamations and the decline in union density', Journal of Industrial Relations, vol. 41, no. 1, March 1999, pp. 35-52.

152. Early expositions of the 'organising model' in the United States are found in Andy Banks and Jack Metzgar, 'Participating in management: Union organising on a new terrain', Labor Research Review, vol. 14, no. 1, 1989, pp. 1-55; Tom Conrow, 'Contract servicing from an organising model: Don't bureaucratize, organize!', Labor Research Review, vol. 17, no. 1, pp. 45-59.

153. There is an extensive international literature in support of the 'organising model'. See, for example, the studies in Fairbrother and Yates (eds), Trade Unions in Renewal. Also those in Kate Bronfenbrenner, Shelton Friedman, Richard W. Hurd, Rudolph A. Oswald and Ronald L. Seeber (eds), Organizing to Win: New Research on Union Strategies, IRL Press, Ithica, 1998; Kate Bronfenbrenner, 'The role of union strategies in NLRB certification election', Industrial and Labor Relations, vol. 50, no. 2, 1997, pp. 195-212; Edmund Heery, Melanie Simms, Dave Simpson, Rick Delbridge and John Salmon, 'Organising unionism comes to the UK', Employee Relations, vol. 22, no. 1, 2000, pp. 39-52. For the 'organising model' in Australia, see Peetz, Brave New Work Places, pp. 163-65; Peetz, Pocock and Houghton, 'Organisers' roles transformed?' pp. 151-66; Rae Cooper, 'Peak Council organising at work: ACTU Strategy 1994-2000', Labour \& Industry, vol. 14, no. 1, pp. 1-15; Bob Carter and Rae Cooper, 'The organising model and the management of change: A comparative study of unions in Australia and Britain', Relations Industrielles/Industrial Relations, vol. 57 no. 4, Autumn 2002, pp. 712-42; Rae Cooper, 'Getting organised? A white-collar union responds to membership crisis', Journal of Industrial Relations, vol. 43, no. 4, December 2001, pp. 1-15; Gerard Griffin and Rosetta Moors, 'The fall and rise of organising in a blue-collar union', Journal of Industrial Relations, vol. 46, no. 1, pp. 39-52.

154. Cooper, 'Getting organised?', pp. 1-15; Griffin and Moors, 'The fall and rise of organising in a bluecollar union', pp. 39-52; Bradon Ellem, “'We're solid": Union renewal at BHP Iron Ore, 1999-2002', International Journal of Employment Studies, October 2002, pp. 23-46; Bradon Ellem, 'New unionism in the old economy: Community and collectivism in the Pilbara mining towns', Journal of Industrial Relations, vol. 45, no. 4, December 2003, pp. 423-41.

155. Rae Cooper, 'Trade unionism in 2001', Journal of Industrial Relations, vol. 44, no. 2, June 2002, pp. 247-50; Peetz, Brave New Work Places, p. 163; Gerard Griffin, 'Australian unions: Still in crisis', in Craig Phelan, Trade Union Reviltalisation: Trends and Perspectives in 34 Countries, Peter Lang, Bern, 2007, p. 559.

156. For a critical analysis, see Ruth Barton, D. Snell and Peter Fairbrother, 'Unions in the Twenty-First Century and beyond: The multiple dimensions of union renewal', in Unions in the Twenty-First Century and Beyond: The Environment, Politics and Education Conference, 17-18 November 2008, Monash University, Melbourne; Bradley Bowden, 'The organising model in Australia: A reassessment', Labour \& Industry, vol. 20, no. 2, December 2009, pp. 138-58. 
157. For a detailed study of this campaign, see Kathie Muir, Worth Fighting For: Inside the Your Rights at Work Campaign, UNSW Press, Sydney, 2008.

158. Australian, 17-18 May 2008, pp. 1, 19.

159. Sydney Morning Herald, 20 September 2010, pp. 1-2.

160. T. Moroney, 'Foreword', in Lane, Dawn to Dusk, p.17.

161. Ibid., p. 19. 